\title{
Progress in Molecular Uranium-Nitride Chemistry
}

David M. King and Stephen T. Liddle*

School of Chemistry, University of Nottingham, University Park, Nottingham, NG7 2RD, UK.

*E-mail: stephen.liddle@nottingham.ac.uk

Keywords: Uranium, nitride, matrix isolation, organometallic chemistry

\begin{abstract}
The coordination, organometallic, and materials chemistry of uranium nitride has long been an important facet of actinide chemistry. Following matrix isolation experiments and computational characterisation, molecular, solution-based uranium chemistry has developed significantly in the last decade or so culminating most recently in the isolation of the first examples of long-sought terminal uranium nitride linkages. Herein, the field is reviewed with an emphasis on well-defined molecular species.
\end{abstract}




\section{Contents}

1. Introduction

2. Spectroscopic Isolation of Uranium Nitrides

2.1. UN and NUN

2.2. NUO

2.3. $\mathrm{EUF}_{3}(\mathrm{E}=\mathrm{N}$ or $\mathrm{P})$

3. Molecular Uranium Nitrides

3.1. Attempts with Nitride Transfer Reagents and Dinitrogen Activation

3.2. Bridging Uranum Nitrides

3.3. Photochemically Generated Uranium Nitrides

\subsection{Terminal Uranium Nitrides}

4. Summary and Outlook

Acknowledgements

References

\section{Introduction}

Investigations into the chemical bonding and reactivity of actinide elements are vital for developing future nuclear applications, ameliorating existing legacy waste issues, as well as furthering our fundamental understanding of the f block elements. ${ }^{1}$ In the past two decades, non-aqueous chemistry has undergone a rapid expansion, ${ }^{2-4}$ in particular multiple bonds concerning $\mathrm{U}=\mathrm{O},{ }^{5-14} \mathrm{U}=\mathrm{N},{ }^{6,9,15-41}$ and $\mathrm{U}=\mathrm{E}(\mathrm{E}=\mathrm{S}, \mathrm{Se}, \mathrm{Te})^{12,42}$ have been investigated with great interest. Furthermore recent developments into $\mathrm{U}=\mathrm{C}$ multiple bonds means they now represent a burgeoning field of research. ${ }^{17,43-57}$ However, due to the prominent paucity of reports of formal $\mathrm{U} \equiv \mathrm{N}$ triple bonds in uranium nitrides significant attention focussed on the isolation of a terminal uranium-nitride linkage in order to address the lack of knowledge of its intrinsic physicochemical properties.

Uranium mononitride has long been considered a suitable material for Generation IV fast spectrum nuclear reactors such as the gas-cooled, lead-cooled and sodium-cooled fast reactors as well as new concepts for light-water reactors. ${ }^{58,59}$ Binary UN is regarded a 
superior candidate over uranium oxide fuels due to its higher melting point $\left(\sim 2850{ }^{\circ} \mathrm{C}\right)$, higher thermal conductivity and advantageously increased density $\left(14.32 \mathrm{~g} \mathrm{~cm}^{-3}\right){ }^{60}$

Uranium nitride exists in three stoichiometric ratios; $\mathrm{UN}, \mathrm{U}_{2} \mathrm{~N}_{3}$ and $\mathrm{UN}_{2} . \mathrm{U}_{2} \mathrm{~N}_{3}$ can be synthesised from uranium metal and $\mathrm{N}_{2}$ at $850{ }^{\circ} \mathrm{C}$, and subsequent decomposition to binary $\mathrm{UN}$ is achieved via further heating to $1150{ }^{\circ} \mathrm{C} .{ }^{61} \mathrm{~A}$ number of techniques have been developed to produce uranium nitride from $\mathrm{UO}_{2}$. The most common of these is carbothermic reduction, which despite extensive research still requires expensive infrastructure and, due to relatively high carbon and oxygen content, often results in contamination by impurities. ${ }^{62-66}$ Alternatively, sol-gel methods have been utilised to synthesise UN. There have also been reports of these two techniques being applied in conjunction. ${ }^{59}$ Less energetically demanding routes have been proposed by reacting UC or $\mathrm{UF}_{4}$ with ammonia, however synthetic routes utilising $\mathrm{UO}_{2}$ or uranium metal are more feasible on industrial scales due to the extent by which they are available, both commercially and naturally. ${ }^{67-69}$ A relatively economical technique compared to carbothemic reduction has been developed, where $\mathrm{UN}$ is synthesised via ball-milling of uranium metal with $\mathrm{N}_{2}$ to afford high purity $\mathrm{UN}{ }^{58}$ However, despite the research conducted in this area the synthesis of UN and study of the bonding and reactivity of the $\mathrm{U} \equiv \mathrm{N}$ fragment remains largely unexplored. As a result, significant attention has been focussed on utilising molecular precursors and matrix isolation experiments to probe the nature of uranium nitrides.

\section{Spectroscopic Isolation of Uranium Nitrides}

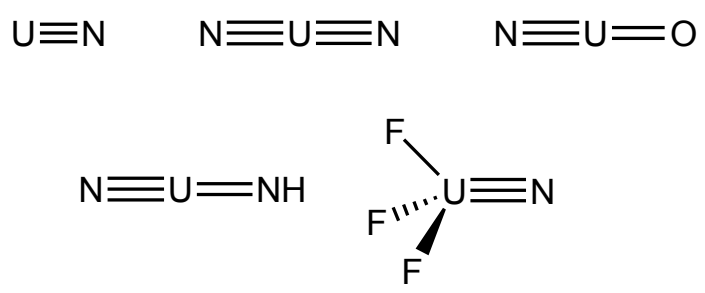

Figure 1 - Spectroscopically Studied Molecular Nitrides 


\section{1. $U N$ and $N U N$}

In 1976 Green and Reedy first observed UN as part of an argon matrix isolation infra-red (IR) study. At $14 \mathrm{~K}$ uranium atoms were produced by a hollow cathode sputtering device with argon (Ar) which was subsequently exposed to low concentrations of $\mathrm{N}_{2}(0.05 \%$ in Ar) or $\mathrm{NO}_{2}$. Upon annealing, an absorbance at $1001 \mathrm{~cm}^{-1}$ was observed which was attributed to UN. In addition, a tentative assignment of $1051 \mathrm{~cm}^{-1}$ was given to the $v_{3}$ absorption of NUN. ${ }^{70}$ In 1993 Andrews and co-workers examined the reactivity of laser ablated uranium atoms with molecular nitrogen in an Ar matrix at $12 \mathrm{~K}$. The only product formed was determined to be linear NUN which was characterised through $v_{3}$ absorption at $1051 \mathrm{~cm}^{-1}$ and this was confirmed by isotopic labelling which supported the previous observation by Green. Although IR inactive $v_{1}$ modes are predicted to arise at $1008 \mathrm{~cm}^{-1}$, the absence of such bands suggests linearity within these species. The NUN molecule is synthesised through uranium atom insertion into a single $\mathrm{N}_{2}$ molecule and the reaction is enhanced by UV (ultraviolet) photolysis which helps overcome the activation energy for reaction. At high $\mathrm{N}_{2}$ concentrations the nitrogen complexes $\mathrm{UN}_{2}-\mathrm{N}_{2}$ and $\mathrm{UN}_{2}-\left(\mathrm{N}_{2}\right)_{2}$ were identified by $v_{3}$ absorbances at 1041 and $1032 \mathrm{~cm}^{-1}$, respectively. ${ }^{71}$ An extension of this work was reported in 1998 identifying two previously unreported uranium nitrides, $\mathrm{U}(\mu$ $\mathrm{N})_{2} \mathrm{U}$ and $\mathrm{NU}(\mu-\mathrm{N})_{2} \mathrm{U}$ (for IR absorbances see Table 1), which can be detected through laser ablation of uranium in condensing pure $\mathrm{N}_{2}$ as minor products along with the major product of NUN. Quasirelativistic density functional theory (DFT) calculations revealed predicted ground states for UN and NUN of ${ }^{4} \Sigma$ and ${ }^{1} \Sigma_{g}$, respectively. Bond lengths for UN and NUN of 1.746 and $1.717 \AA$, respectively, were calculated wherein NUN exhibits a linear geometry in agreement with other theoretical results. ${ }^{72,73}$ Viswanathan conducted a similar matrix isolation study and reported that increasing concentrations of $\mathrm{N}_{2}$ yielded increasing amounts of UN. It was therefore suggested that at high $\mathrm{N}_{2}$ concentrations new reaction channels are generated through the formation of $\mathrm{N} \cdot$ and $\mathrm{N}_{3}$ radicals which can react with uranium atoms or NUN to yield $U N{ }^{74}$ 


\begin{tabular}{lrr}
\hline Compound & $\mathrm{U} \equiv \mathrm{N}^{14} \mathrm{~cm}^{-1}$ & $\mathrm{U} \equiv \mathrm{N}^{15} \mathrm{~cm}^{-1}$ \\
\hline $\mathrm{U} N$ & 1001 & 969 \\
$\mathrm{U} N_{2}$ & 1051 & 1019 \\
$\mathrm{U} N_{2}(\mathrm{~N})_{2}$ & 1041 & 1010 \\
$\mathrm{U} N_{2}\left(\mathrm{~N}_{2}\right)_{2}$ & 1032 & 1001 \\
& 670 & 648 \\
$\mathrm{U}(\mu-N)_{2} \mathrm{U}$ & 580 & 562 \\
$\mathrm{NU}(\mu-\mathrm{N})_{2} \mathrm{U}$ & 968 & 938 \\
$\mathrm{NU}(\mu-N)_{2} \mathrm{U}$ & 844 & 817 \\
$N U \mathrm{NO}$ & 984 & 953 \\
{$[N U]^{+}[\mathrm{NO}]^{-}$} & 1017 & 987 \\
$N U F_{3}$ & 938 & - \\
$N U N H$ & 967 & 937 \\
$\mathbf{2 2}$ & 955 & 930 \\
$\mathbf{2 3}$ & 936 & 900 \\
$\mathbf{2 7}$ & 914 & 883 \\
$\mathbf{3 1}$ & 856 & 827 \\
\hline
\end{tabular}

Table 1 - Experimentally observed IR $\mathrm{U} \equiv \mathrm{N}$ absorbances and isotopomer shifts.

\subsection{NUO}

In 1997 Andrews and co-workers investigated the reactivity of laser ablated uranium towards $\mathrm{NO}$ in argon matrices at 6-7 K. This reaction predominantly formed the insertion product NUO which exhibits characteristic IR absorption bands at 984 (U-N) and 819 $\mathrm{cm}^{-1}(\mathrm{U}-\mathrm{O})$. Quasirelativistic DFT calculations supported the assignment and predicted a linear geometry and a ${ }^{2} \Phi$ electronic ground state. Also characterised in this report is the uranyl analogue $[\mathrm{NUO}]^{+}[\mathrm{NO}]^{-75} \mathrm{NUO}$ and $[\mathrm{NUO}]^{+}$have also been isolated in neon matrices whilst $[\mathrm{NUO}]^{+}$has been observed in the gas phase through mass spectrometry. ${ }^{76,77}$ Collision-induced-dissociation experiments and ligand exchange reactions resulted in the identification of $[\mathrm{NUO}]^{+}$from the exothermic reaction of $\mathrm{UN}^{+}$ (generated from $\mathrm{U}^{+}+\mathrm{NO}_{2}$ ) with $\mathrm{O}_{2}, \mathrm{CO}_{2} \mathrm{SO}_{2}$ and $\mathrm{COS}$. The study also deduced the heat of formation for [NUO] ${ }^{+}$to be $\Delta H_{\mathrm{f}}{ }^{\circ}=145.6 \pm 29.2 \mathrm{kcal} \mathrm{mol}^{-1}$ and theoretical calculations conducted by Pyykkö and Schwarz predicted the U-N bond distances to be shorter in comparison to the U-O bond lengths. ${ }^{76,78} \mathrm{NUN}$ and $[\mathrm{NUO}]^{+}$are isoelectronic analogues of the $\left[\mathrm{UO}_{2}\right]^{2+}$ dication and thorough computational studies have been conducted on the species, deducing that the U-N bonding in NUN and $[\mathrm{NUO}]^{+}$is significantly more covalent than in the $\mathrm{U}-\mathrm{O}$ bonding exhibited in $\left[\mathrm{UO}_{2}\right]^{2+}$ and $[\mathrm{NUO}]^{+}{ }^{79}$ 


\section{3. $E U F_{3}(E=N$ or $P)$}

The terminal nitrido and phosphido molecules $\mathrm{NUF}_{3}$ and $\mathrm{PUF}_{3}$ have been observed using IR spectroscopy in the reaction of laser-ablated uranium atoms with $\mathrm{EF}_{3}(\mathrm{E}=\mathrm{N}, \mathrm{P})$. The $\mathrm{U} \equiv \mathrm{N}$ vibrational absorbance was assigned to a band at $938 \mathrm{~cm}^{-1}$, whilst $\mathrm{U} \equiv \mathrm{P}$ was not observable. Ab initio studies support the assignment of the IR bands for these species with calculated bond lengths for $\mathrm{U} \equiv \mathrm{N}$ and $\mathrm{U} \equiv \mathrm{P}$ of 1.76 and $2.40 \AA$ (CASPT2) and effective bond orders of 2.78 and 2.40 , respectively. The studies also calculated the $U \equiv N$ bonding in $\mathrm{NUF}_{3}$ to be stronger and more covalent $\left(460 \mathrm{~kJ} \mathrm{~mol}^{-1}\right)$ than the $\mathrm{U} \equiv \mathrm{P}$ bonding in $\mathrm{P} \equiv \mathrm{UF}_{3}\left(176 \mathrm{~kJ} \mathrm{~mol}^{-1}\right)$ demonstrating that the $\mathrm{U} 5 \mathrm{f}$ orbitals achieve greater orbital overlap to $\mathrm{N}$ than $\mathrm{P}$, therefore bonding more effectively with the smaller, harder nitrogen ligand. ${ }^{80}$

A further study by Andrews reported the exposure of laser-ablated uranium atoms to $\mathrm{N}_{2}$ and $\mathrm{H}_{2}$ in an argon matrix at $5 \mathrm{~K}$. Aside from the formation of $\mathrm{NUN}$ and $\mathrm{UN}$, the new uranium(V) nitride imide molecule $\mathrm{N} \equiv \mathrm{U}=\mathrm{NH}$ was characterised through the identification of one N-H $\left(3350 \mathrm{~cm}^{-1}\right)$, two U-N stretching modes $\left(\mathrm{U} \equiv \mathrm{N}=967 \mathrm{~cm}^{-1}, \mathrm{U}=\mathrm{N}\right.$ $\left.=752 \mathrm{~cm}^{-1}\right)$ and one UNH bending mode $\left(433 \mathrm{~cm}^{-1}\right)$ in the IR spectrum of NUNH. ${ }^{81}$ These assignments were fully supported by isotopic labelling studies. It is proposed that initially formed NUN reacts under UV irradiation with hydrogen atoms to form $\mathrm{N} \equiv \mathrm{U}=\mathrm{NH}$. Although not isolated, the mixed azide/nitride species $\mathrm{NUN}_{3}$ has been investigated using computational calculations. This complex was calculated to be stable in the singlet and triplet states and linear with a calculated $\mathrm{U} \equiv \mathrm{N}$ bond distance of 1.73 $\AA{ }^{82}$ In addition, Gagliardi and Pyykkö theoretically investigated the metal actinide nitrido species $[\mathrm{NUOs}]^{-}$, NUIr, $[\mathrm{NUPt}]^{+}$and $[\mathrm{NUAu}]^{2+}$ as analogues to uranyl. Calculations in the singlet and triplet states gave $\mathrm{U} \equiv \mathrm{N}$ bond lengths of $1.76,1.72,1.69$ and $1.68 \AA$, respectively, and each molecule exhibits the electronic ground state and first excited state of ${ }^{1} \Sigma^{+}$and ${ }^{3} \Phi$, respectively. Of most significance is the neutral molecule NUIr. Calculations suggest two strong triple bonds involving $\sigma$ - and $\pi$-components, which would therefore be isoelectronic with NUN and uranyl. A synthetic route was also proposed towards the isolation of NUIr using either simultaneous evaporation of the three elements, or to start with the diatomic species IrN or $\mathrm{UN} .{ }^{83}$ The synthesis of these simple 
uranium nitride complexes, albeit at very low temperatures under exotic experimental conditions, led to many attempts to synthesise the terminal uranium nitride linkage under ambient conditions and only very recently has this challenge been successfully been met.

\section{Molecular Uranium Nitrides}

\subsection{Attempts with Nitride Transfer Reagents and Dinitrogen Activation}

Initial attempts to synthesise the terminal nitrido functionality were reported by Cummins and co-workers in 2000. Reaction of the nitride transfer reagent $\mathrm{Li}(\mathrm{dbabh})(\mathrm{Hdbabh}=$ 2,3:5,6-dibenzo-7-azabicyclo[2.2.1] hepta-2,5-diene) with $\left[\mathrm{UI}_{3}(\mathrm{THF})_{4}\right]$ did not yield the expected uranium nitride product as is observed analogously for chromium. ${ }^{84}$ Instead, the uranium(V)-hexakisamido complex $\left[\mathrm{Li}(\mathrm{THF})_{\mathrm{x}}\right]\left[\mathrm{U}(\mathrm{dbabh})_{6}\right]$ was isolated and characterised. ${ }^{85}$ Cummins subsequently reported that mixing trivalent $\mathrm{U}^{\mathrm{III}}$ and $\mathrm{Mo}^{\mathrm{III}}$ precursors, $\left[\mathrm{U}\left(\mathrm{THF}\left\{\mathrm{N}\left({ }^{t} \mathrm{Bu}\right) \mathrm{Ar}\right\}_{3}\right](\mathbf{1})\left(\mathrm{Ar}=3,5-\mathrm{C}_{6} \mathrm{H}_{3} \mathrm{Me}_{2}\right)\right.$ and $\left[\mathrm{Mo}\{\mathrm{N}(\mathrm{R}) \mathrm{Ph}\}_{3}\right]\left[\mathrm{R}={ }^{t} \mathrm{Bu}\right.$ or $\mathrm{Ad}\left(\mathrm{Ad}=1\right.$-adamantyl)], under an $\mathrm{N}_{2}$ atmosphere yielded the heterodinuclear complex $\left[\mathrm{U}\left\{\mathrm{N}\left({ }^{t} \mathrm{Bu}\right) \operatorname{Ar}\right\}_{3}\left(\mu-\eta^{1}: \eta^{1}-\mathrm{N}_{2}\right) \mathrm{Mo}\{\mathrm{N}(\mathrm{R}) \mathrm{Ph}\}_{3}\right](2)\left(\mathrm{R}={ }^{t} \mathrm{Bu}, \mathrm{Ad}\right)$ and not the expected N-N cleavage product (Scheme 1). Complex 2 exhibits an N-N bond length of 1.232(11) $\AA$ that is significantly longer than in free $\mathrm{N}_{2}$ suggesting reduction to an $\left[\mathrm{N}_{2}\right]^{2-}$ unit, whilst the uranium-amide bond lengths are consistent with tetravalent uranium(IV). It is proposed that the dinitrogen complex $\left[\mathrm{Mo}\{\mathrm{N}(\mathrm{R}) \mathrm{Ph}\}_{3}\left(\mathrm{~N}_{2}\right)\right]$ is initially formed but trapped by the strongly Lewis acidic uranium complex, generating the observed dinuclear product. $^{86}$

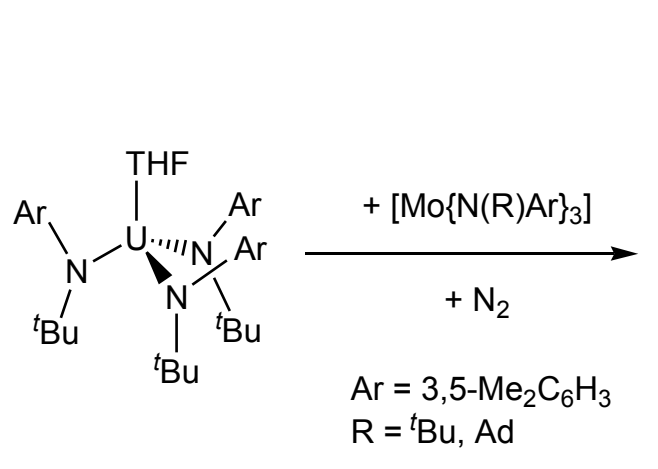

1

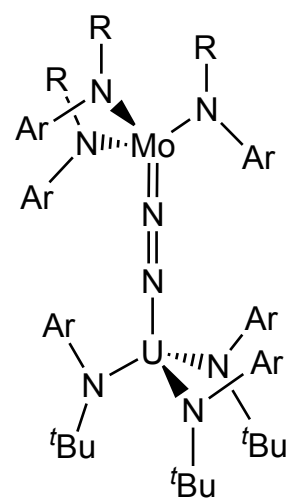

2

Scheme 1 - Synthesis of $\left[U\{N(R) A r\}_{3}\left(\mu-\eta^{1}: \eta^{1}-N_{2}\right) \operatorname{Mo}\{N(R) P h\}_{3}\right], 2 .{ }^{86}$ 


\subsection{Bridging Uranum Nitrides}

The first uranium nitrido complex to be isolated in any significant quantity was synthesised via the reductive cleavage of dinitrogen. Despite several reports of uranium dinitrogen bonding, this report by Gambarotta is still the only complex to effect dinitrogen cleavage and nitride formation. ${ }^{87-92}$ Treatment of $\left[\left\{\mathrm{Et}_{8}-\right.\right.$ calix(4)tetrapyrrole $\} \mathrm{U}(\mathrm{DME})][\mathrm{K}(\mathrm{DME})]$ (3) with $\mathrm{K}\left(\mathrm{C}_{10} \mathrm{H}_{8}\right)$ under an $\mathrm{N}_{2}$ atmosphere afforded the mixed-valent dinuclear $\mathrm{U}^{\mathrm{IV}} / \mathrm{U}^{\mathrm{V}} \mu$-nitrido complex $\left[\left\{\mathrm{K}(\mathrm{DME})\left(\mathrm{Et}_{8}-\right.\right.\right.$ calix[4]tetrapyrrole) $\left.\mathrm{U}_{2}(\mu-\mathrm{NK})_{2}\right]\left[\mathrm{K}(\mathrm{DME})_{4}\right](4)$, Scheme 2. The U-N $\mathrm{N}_{\text {nitride }}$ bond lengths of 2.076(6) and 2.099(5) A, Figure 2, are comparable to uranium nitrogen double bonds ${ }^{4}$ and the nitride source $\left(\mathrm{N}_{2}\right)$ was confirmed through isotopic labelling studies. ${ }^{93}$

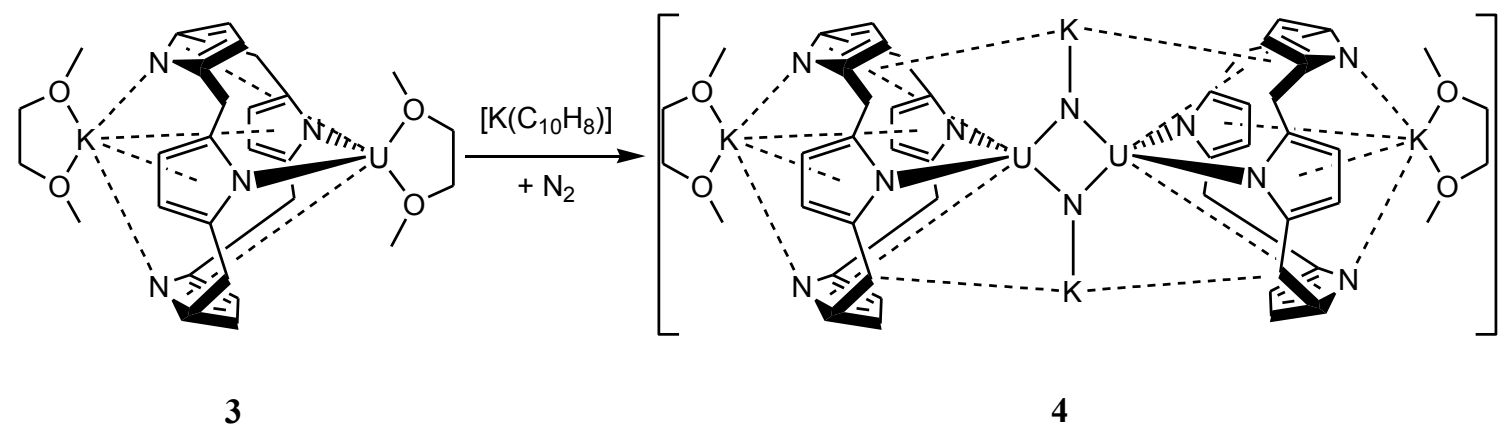

Scheme 2 - Synthesis of $\left[\left\{\text { K(DME) }\left(\mathrm{Et}_{8} \text {-calix }[4] \text { tetrapyrrole }\right) U\right\}_{2}(\mu-\mathrm{NK})_{2}\right]\left[\mathrm{K}(\mathrm{DME})_{4}\right], 4 .^{93}$ Ethyl substituents and $\left[\mathrm{K}(\mathrm{DME})_{4}\right]$ are omitted for clarity.

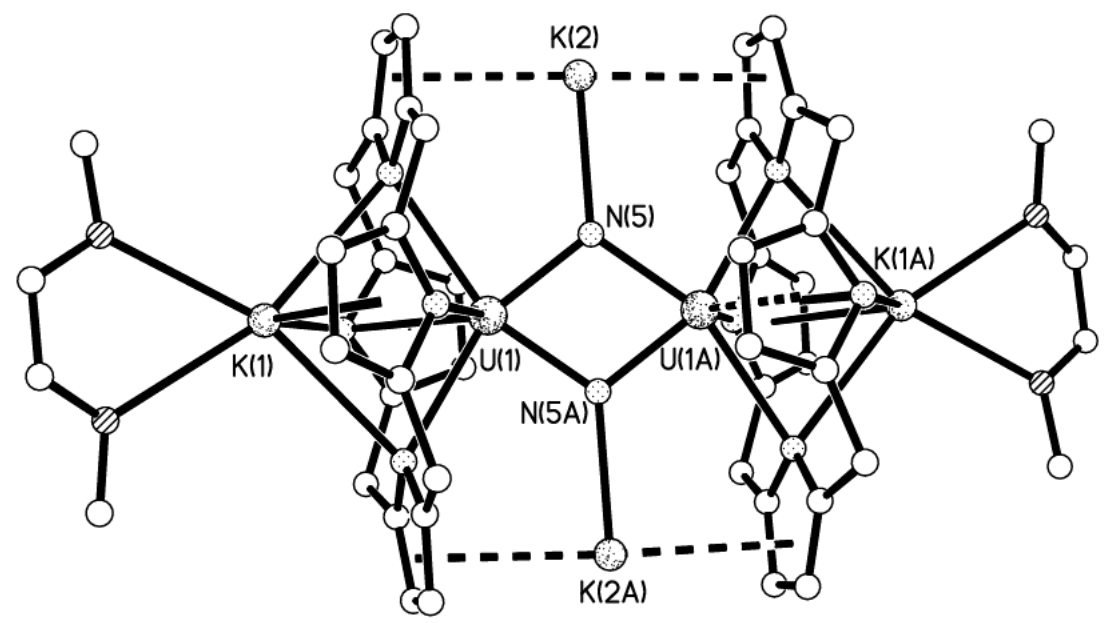

Figure 2 - Molecular structure of the anion of 4, hydrogen atoms and ethyl groups have been removed for clarity. 


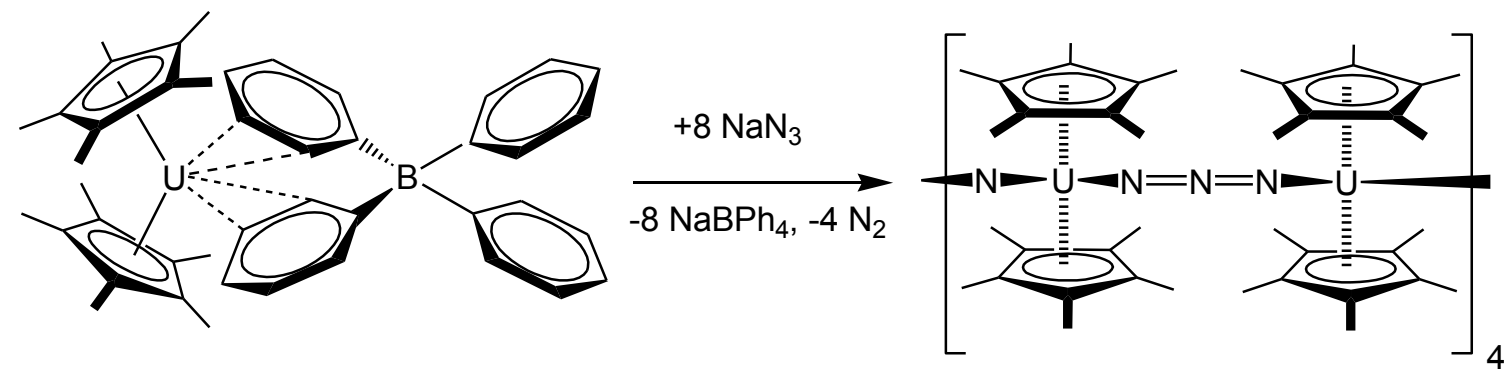

5

Scheme 3 -Synthesis of $\left.\left[\left(C p^{*}\right)_{2} U(\mu-N) U\left(\mu-N_{3}\right)(C p *)_{2} U\right)_{2}\right]_{4}, 6 .{ }^{94}$

Evans and co-workers synthesised an unexpected and unusual nitrido complex formed from the reaction of $\left[\mathrm{U}\left(\mathrm{C}_{5} \mathrm{Me}_{4} \mathrm{R}\right)_{2}\right]\left[(\mu-\mathrm{Ph})_{2} \mathrm{BPh}_{2}\right](5)(\mathrm{R}=\mathrm{Me}, \mathrm{H})$ with $\mathrm{NaN}_{3}$. On the basis of previous chemistry exhibited by this system the predicted product was a uranium azido complex. However, the reaction afforded the alternating nitrido-azido tetravalent octauranium ring, $\left.\left[\left(\mathrm{C}_{5} \mathrm{Me}_{4} \mathrm{R}\right)_{2} \mathrm{U}(\mu-\mathrm{N}) \mathrm{U}\left(\mu-\mathrm{N}_{3}\right)\left(\mathrm{C}_{5} \mathrm{Me}_{4} \mathrm{R}\right)_{2} \mathrm{U}\right)_{2}\right]_{4}$ (6) (Scheme 3 and Figure 3) which exhibits U-N nitride bond lengths of 2.047(6) - 2.090(8) $\AA$ which are within the observed U-N double bond range. ${ }^{94}$ The U-N-U bonding is not localised and as a result it is suggested a $\mathrm{U}=\mathrm{N}=\mathrm{U}$ description of the bonding is most appropriate. Formally, eight $\mathrm{U}^{\mathrm{III}}$ centres are oxidised to $\mathrm{U}^{\mathrm{IV}}$ in the reduction of four azide ligands to form the nitrides, however why this occurs in this case, while other uranium azide complexes remain stable, is currently open to debate. ${ }^{94}$ 


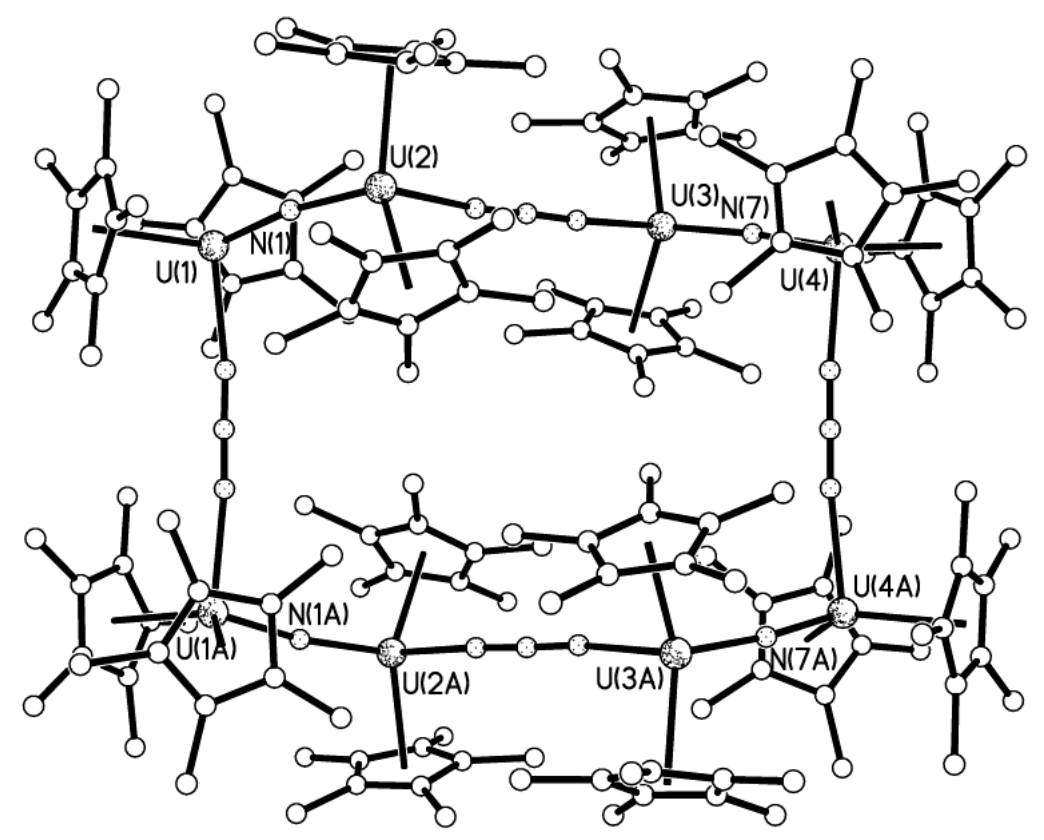

Figure 3 - Molecular structure of 6 with hydrogen atoms omitted for clarity.

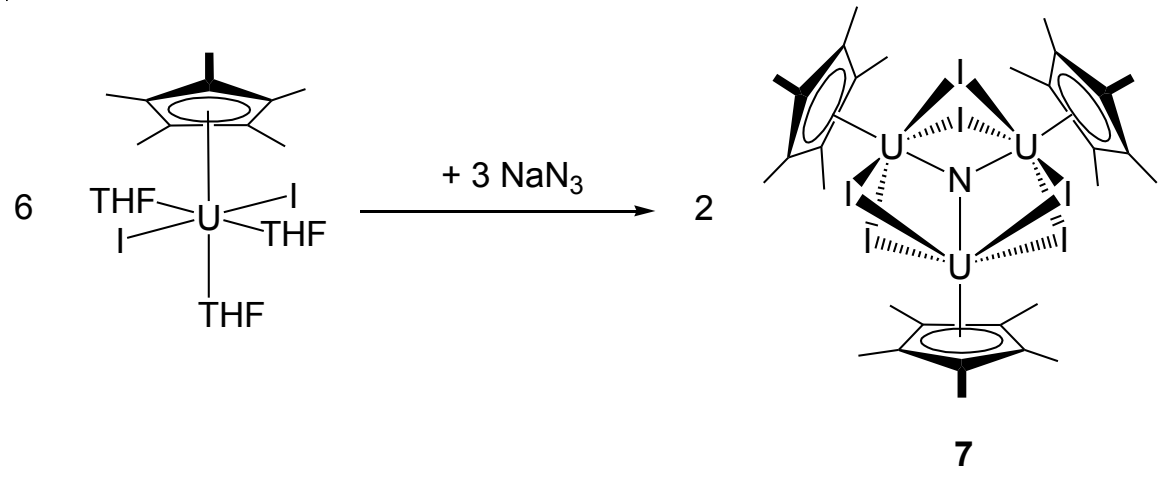

Scheme 4 - Synthesis of $\left[\left\{C p * U(\mu-I)_{2}\right\}_{3}\left(\mu_{3}-N\right)\right], 7 . .^{95}$ 


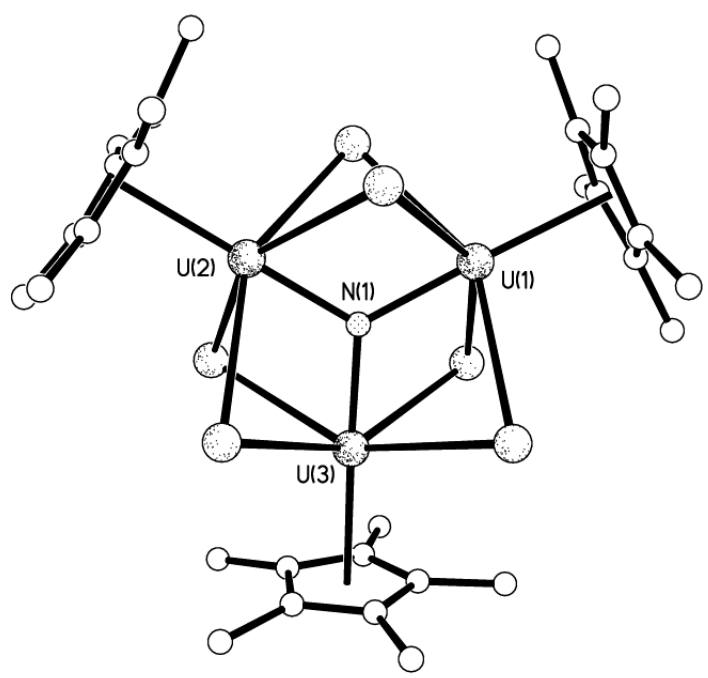

Figure 4 - Molecular structure of 7 with hydrogen atoms omitted for clarity.

Evans has also investigated the reductive capacity of $\left[\mathrm{Cp}^{*} \mathrm{UI}_{2}(\mathrm{THF})_{3}\right]$ towards sodium azide. The resultant product was a trinuclear uranium cluster featuring bridging iodide ligands and a $\mu_{3}$-nitrido centre, $\left[\left\{\mathrm{Cp} * \mathrm{U}(\mu-\mathrm{I})_{2}\right\}_{3}\left(\mu_{3}-\mathrm{N}\right)\right](7)\left(\mathrm{Cp}^{*}=\mathrm{C}_{5} \mathrm{Me}_{5}\right)$ (Scheme 4 and Figure 4) synthesised through the reduction of azide by $\mathrm{U}^{\mathrm{III}}$ centres in $33 \%$ yield. However, X-ray crystallographic techniques cannot discern the nitride from an oxide or indeed a hydroxide which may be present as a result of the presence of adventitious oxygen. ${ }^{95}$ A collation of U-Cp and U-I bond distances for known $\mathrm{U}^{\mathrm{III}}$ and $\mathrm{U}^{\mathrm{IV}}$ complexes was studied to ascertain the oxidation state of the uranium centres. However, unfortunately this could not provide unambiguous confirmation. Consequently, isotopic labelling studies analysed by atmospheric pressure chemical ionisation mass spectrometry were conducted which deduced the central atom was indeed nitrogen. This was confirmed when the oxide complex, synthesised separately, proved to have different analytical properties (NMR, space group, colour). ${ }^{96}$ Support for this formulation was provided through extensive DFT and CASPT2 analysis which calculated the uranium spin densities to be equivalent and therefore $\mathrm{U}^{\mathrm{IV}}$. As a consequence, this provides evidence to support the assertion that the central atom is indeed a nitride. The experimental U-N $\mathrm{N}_{\text {nitride }}$ bond lengths of 2.138(3), 2.152(3) and 2.157(3) $\AA$ are consistently shorter than known amido bond lengths and agree well with the calculated bond distances. Also reported was the tentative identification of a further polymetallic species, $\left[\mathrm{Cp} * \mathrm{U}\left(\mu_{3}-\mathrm{E}\right)\right]_{8}(\mathrm{E}=\mathrm{N}, \mathrm{O})(\mathbf{8})$, from the reaction of 5 with $\mathrm{KC}_{8}$ under $\mathrm{N}_{2}$, Scheme 5 . X- 
ray crystallographic techniques could not reliably identify $\mathrm{E}$ as oxide or nitride and further characterisation (NMR, mass spectrometry, elemental analysis, isotopic labelling) could not be conducted. DFT and CASPT2 analysis predicted both molecules to be stable. However, experimental values are more consistent with a tetravalent uranium cluster in which $\mathrm{E}$ is a nitride centre based on comparison to calculated $\mathrm{U}-\mathrm{N}$ bond lengths. ${ }^{97}$

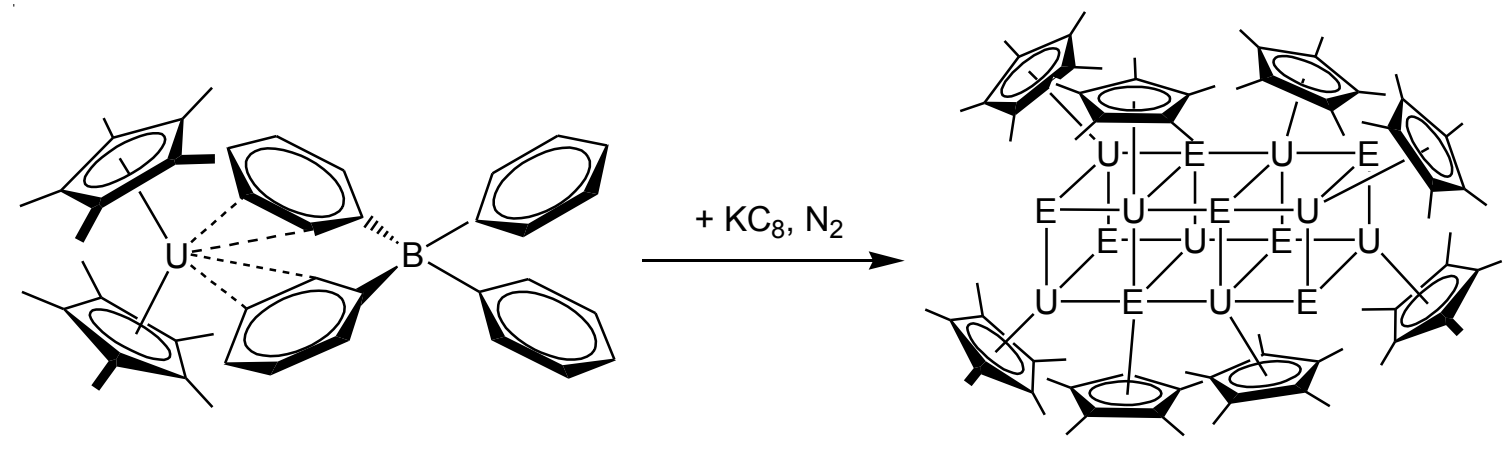

5

8

Scheme 5 - Synthesis of $\left[\mathrm{Cp} * \mathrm{U}\left(\mu_{3}-\mathrm{E}\right)\right]_{8}(E=N, O), 8 .^{97}$

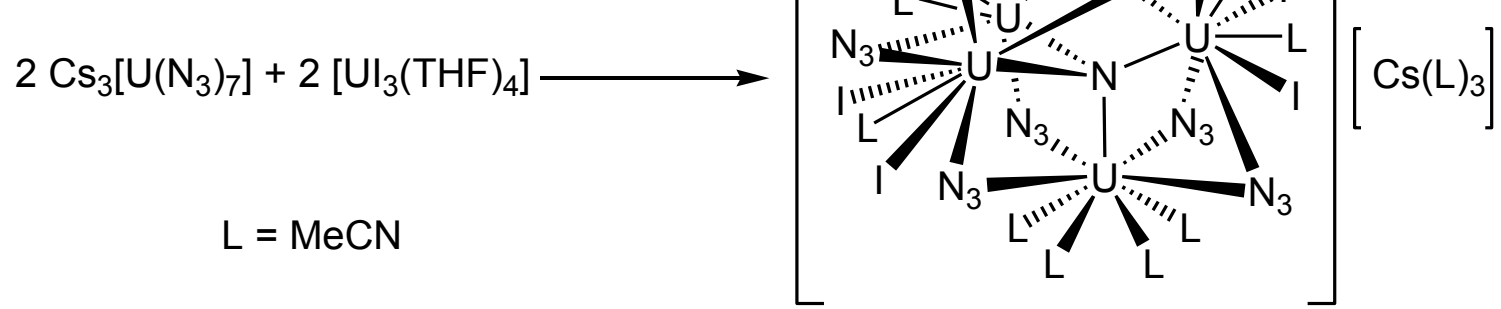

9

Scheme 6 - Synthesis of $\left\{\left[\mathrm{Cs}(\mathrm{MeCN})_{3}\right]\left[\mathrm{U}_{4}\left(\mu_{4}-\mathrm{N}\right)\left(\mu-\mathrm{N}_{3}\right)(\mathrm{MeCN})_{8} \mathrm{I}_{6}\right]\right\}_{x}, 9 .{ }^{98}$

Nitrido cluster chemistry has also been investigated by Mazzanti and co-workers. The group synthesised the heptaazide tetravalent precursor complex $\mathrm{Cs}_{3}\left[\mathrm{U}\left(\mathrm{N}_{3}\right)_{7}\right]$ with a view to subsequent nitride formation. Treatment with $\left[\mathrm{UI}_{3}(\mathrm{THF})_{4}\right]$ yielded the nitrido-azido tetrametallic cluster $\left\{\left[\mathrm{Cs}(\mathrm{MeCN})_{3}\right]\left[\mathrm{U}_{4}\left(\mu_{4}-\mathrm{N}\right)\left(\mu-\mathrm{N}_{3}\right)(\mathrm{MeCN})_{8} \mathrm{I}_{6}\right]\right\}_{\mathrm{x}}(\mathbf{9})$ (Scheme 6). ${ }^{98}$ The nitrido centre of 9 bridges four uranium centres and exhibits $U-N_{\text {nitride }}$ bond lengths ranging 2.271(3) to 2.399(5) $\AA$, Figure 5. The compound is a result of a two-electron 
reduction of an azide by two $\mathrm{U}^{\mathrm{III}}$ centres. It is important to note that to date this is the only isolated molecular nitride which is not stabilised by sterically demanding ancillary ligands; it is proposed the nitrido centre provides an important role in the cluster formation, acting as a template.

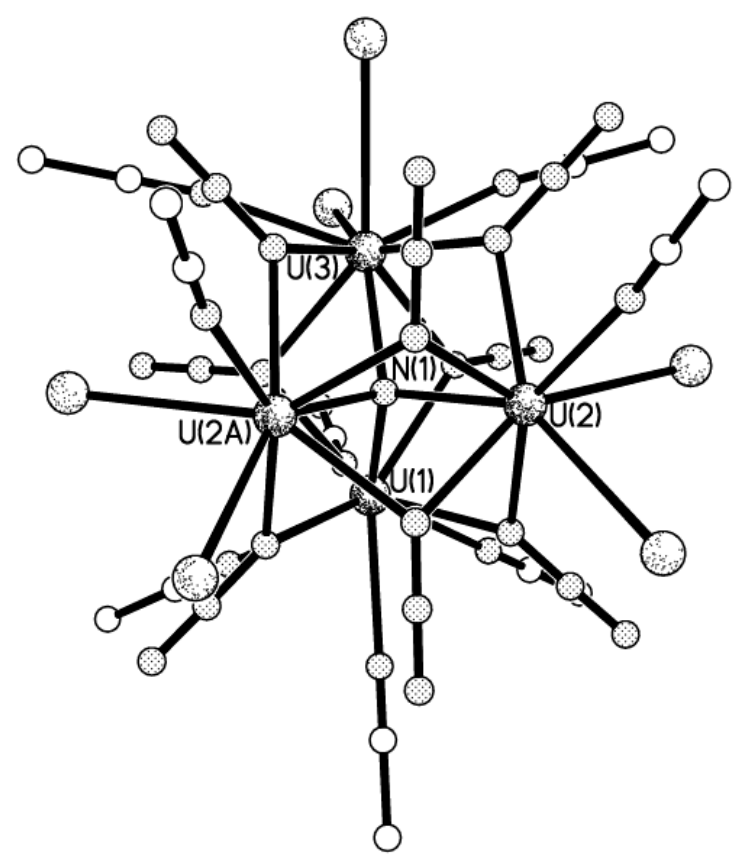

Figure 5 - Molecular Structure of 9, with only the uranium-nitrido core shown for clarity.

The exploitation of the reductive capacity of trivalent uranium to facilitate two-electron redox chemistry with azides has been an area of extensive research in the field of uranium imido complexes. In general the reduction of organic azides $\left(\mathrm{RN}_{3}\right)$ with uranium results in the formation of $\mathrm{U}=\mathrm{NR}$ complexes. ${ }^{15,16,18,19,21,26,29}$ Consequently, research turned to inorganic azides as a source of nitrido synthons. Cummins reported the first example of a nitridoborate complex of uranium in 2009, Scheme 7. Treatment of 1 with $\left[\mathrm{N}^{n} \mathrm{Bu}_{4}\right]\left[\left(\mathrm{N}_{3}\right) \mathrm{B}\left(\mathrm{C}_{6} \mathrm{~F}_{5}\right)_{3}\right]$ afforded the borane-capped pentavalent uranium nitrido complex, $\left[\mathrm{N}^{n} \mathrm{Bu}_{4}\right]\left[\left\{\left(\mathrm{C}_{6} \mathrm{~F}_{5}\right)_{3} \mathrm{BN}\right\} \mathrm{U}\left\{\mathrm{N}\left({ }^{t} \mathrm{Bu}\right) \mathrm{Ar}\right\}_{3}\right]$ (10) with concomitant evolution of $\mathrm{N}_{2}$ in $80 \%$ yield. ${ }^{99}$ The complex features a linear U-N-B $\left[177.8(3)^{\circ}\right]$ unit, Figure 6 , and exhibits a U$\mathrm{N}_{\text {nitride }}$ bond length of 1.916(4) $\AA$ which is comparable with the U- $\mathrm{N}_{\text {imido }}$ distance observed in $\left[\left(\mathrm{Me}_{3} \mathrm{SiN}\right) \mathrm{U}\left(\mathrm{N}^{\prime \prime}\right)_{3}\right][1.910(16) \AA]\left[\mathrm{N}^{\prime \prime}=\mathrm{N}\left(\mathrm{SiMe}_{3}\right)_{2}\right] .{ }^{18}$ Interrogation of $\mathbf{1 0}$ by 
cyclic voltammetry revealed that a reversible one-electron oxidation process to the hexavalent complex was potentially accessible. This oxidation was achieved chemically through the use of 0.5 equivalents of $\mathrm{I}_{2}$ or one equivalent of AgOTf to form $\left[\left\{\left(\mathrm{C}_{6} \mathrm{~F}_{5}\right)_{3} \mathrm{BN}\right\} \mathrm{U}\left\{\mathrm{N}\left({ }^{t} \mathrm{Bu}\right) \mathrm{Ar}_{3}\right](\mathbf{1 1})\right.$ in $82 \%$ yield. The oxidation results in a contraction of the U- $\mathrm{N}_{\text {nitride }}$ bond length by $0.04 \AA$ to 1.880 (4) $\AA$ whilst retaining linearity $[\mathrm{B}-\mathrm{N} \equiv \mathrm{U}=$ $\left.179.4(3)^{\circ}\right]$. The complex also exhibits a lengthening of the B-N bond length upon oxidation from 1.540(6) $\AA$ in $\mathbf{1 0}$ to $1.592(6) \AA$ in 11. This is one of the shortest U-N bonds to be reported in a molecular context. However, attempts to cleave the N-B bond to furnish a terminal uranium nitride complex have thus far proved unsuccessful.
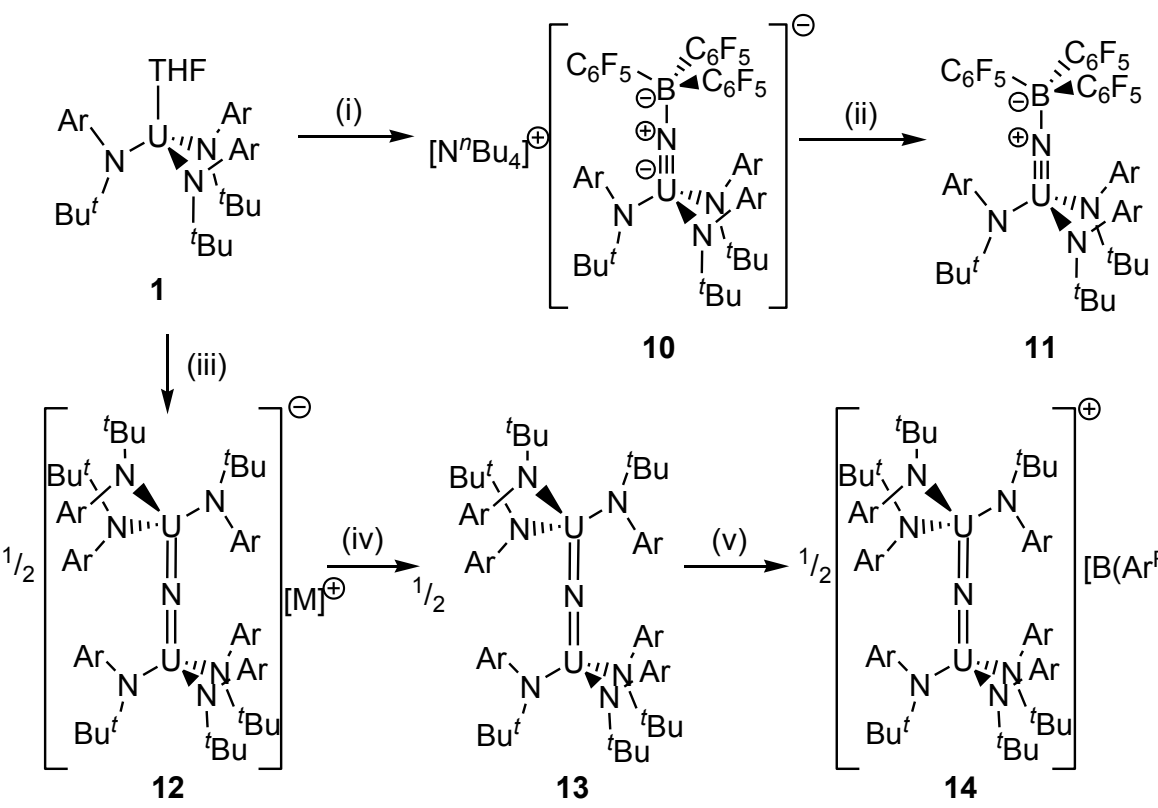

13

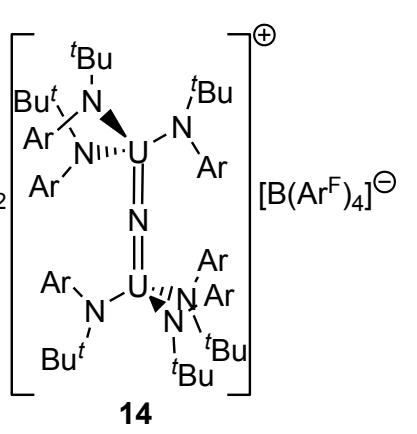

$$
\begin{gathered}
\text { i) } \left.\left.+\left[\mathrm{N}^{n} \mathrm{Bu}_{4}\right]\left[\left(\mathrm{N}_{3}\right) \mathrm{B}\left(\mathrm{C}_{6} \mathrm{~F}_{5}\right)_{3}\right],-\mathrm{N}_{2}, \text { THF. ii }\right)+0.5 \mathrm{I}_{2},-\left[\mathrm{N}^{n} \mathrm{Bu}_{4}\right][\mathrm{l}] . \mathrm{iii}\right)+0.5 \mathrm{MN}_{3},-\mathrm{N}_{2} . \\
\text { iv) }+0.5 \mathrm{AgOTf},-0.5 \mathrm{Ag},{ }_{1}{ }_{2} \text { MOTf. v) } 0.5\left[\mathrm{Cp}_{2} \mathrm{Fe}\right]\left[\mathrm{B}\left(\mathrm{Ar}^{\mathrm{F}}\right)_{4}\right],-0.5 \mathrm{Cp}_{2} \mathrm{Fe} . \\
\mathrm{M}=\mathrm{Na}, \mathrm{N}^{n} \mathrm{Bu}_{4} . \mathrm{Ar}=3,5-\mathrm{Me}_{2} \mathrm{C}_{6} \mathrm{H}_{3} . \mathrm{Ar}^{\mathrm{F}}=3,5-\left(\mathrm{CF}_{3}\right)_{2} \mathrm{C}_{6} \mathrm{H}_{3} .
\end{gathered}
$$

Scheme 7 - Synthesis of 10-14.99, 100 

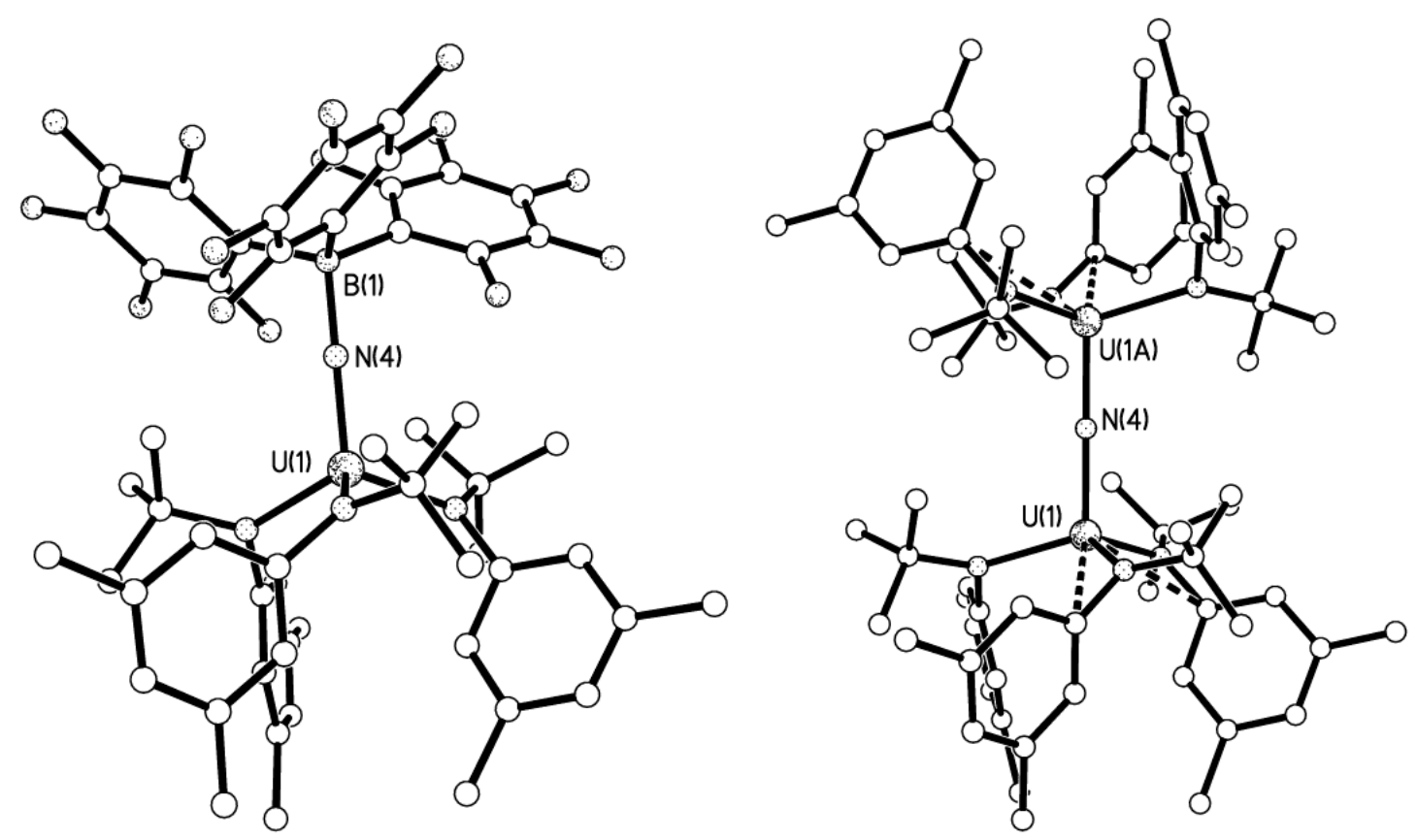

Figure 6 - Representative structures of the uranium nitrides 11 and 13 with hydrogen atoms omitted for clarity.

Shortly following this work attempts to synthesise uranium nitride complexes using unprotected azides were reported by Cummins, Scheme 7. Straightforward addition of $\mathrm{MN}_{3} \quad\left(\mathrm{M}=\mathrm{Na}, \mathrm{N}^{n} \mathrm{Bu}_{4}\right)$ to $\mathbf{1}$ provided the bimetallic $\mathrm{U}^{\mathrm{IV}}$ complex $[\mathrm{M}][(\mu-$ $\left.\mathrm{N})\left\{\mathrm{U}\left[\mathrm{N}\left({ }^{t} \mathrm{Bu}\right) \mathrm{Ar}\right]_{3}\right\}_{2}\right](\mathbf{1 2})$ in good yield. ${ }^{100}$ The neutral mixed valent $\mathrm{U}^{\mathrm{IV} / \mathrm{V}}$ complex $[(\mu-$ $\left.\mathrm{N})\left\{\mathrm{U}\left[\mathrm{N}\left({ }^{t} \mathrm{Bu}\right) \mathrm{Ar}\right\}_{3}\right)_{2}\right]$ (13) was generated through reaction with AgOTf and further oxidised to the cationic $\mathrm{U}^{\mathrm{V} / \mathrm{V}}$ monovalent compound $\left[(\mu-\mathrm{N})\left(\mathrm{U}\left\{\mathrm{N}\left({ }^{t} \mathrm{Bu}\right) \operatorname{Ar}\right\}_{3}\right)_{2}\right]\left[\mathrm{B}\left(\mathrm{Ar}^{\mathrm{F}}\right)_{4}\right]$ (14) $\left[\mathrm{Ar}^{\mathrm{F}}=3,5-\left(\mathrm{CF}_{3}\right)_{2} \mathrm{C}_{6} \mathrm{H}_{3}\right]$ by treatment with $[\mathrm{Cp} 2 \mathrm{Fe}]\left[\mathrm{B}\left(\mathrm{Ar}^{\mathrm{F}}\right)_{4}\right]$. A study of the redox chemistry of 13 supplied evidence for strong communication between the uranium centres with a $\mathrm{K}_{\mathrm{c}} \approx 5.6 \times 10^{17}$ for the comproportionation of $[\mathrm{U}=\mathrm{N}=\mathrm{U}]^{-}$and $[\mathrm{U}=\mathrm{N}=\mathrm{U}]^{+}$. In addition, X-ray crystallographic studies of these three complexes, Figure 6, revealed a decrease in the $\mathrm{U}_{\mathrm{N}} \mathrm{N}_{\text {(nitride) }}$ distances per one-electron oxidation with $\mathrm{U}-\mathrm{N}$ bond lengths of 2.079(av), 2.0625(2) and 2.049(av) Å for 12, 13 and $\mathbf{1 4}$ respectively. The contraction of the $[\mathrm{U}=\mathrm{N}=\mathrm{U}]$ core was assigned to an increase in electrostatics as a result of the removal of non-bonding electrons. The reaction chemistry was also investigated. Addition of $\mathrm{NaCN}$ to $\mathbf{1 4}$ formed the previously reported dinuclear cyanoimide complex [ $\mu$ - 
$\left.\mathrm{NCN})\left\{\mathrm{U}\left(\mathrm{N}\left[{ }^{t} \mathrm{Bu}\right] \mathrm{Ar}\right)_{3}\right\}_{2}\right]^{101}$ through a two-electron reduction and insertion into the nitride bridge by the cyanide anion.

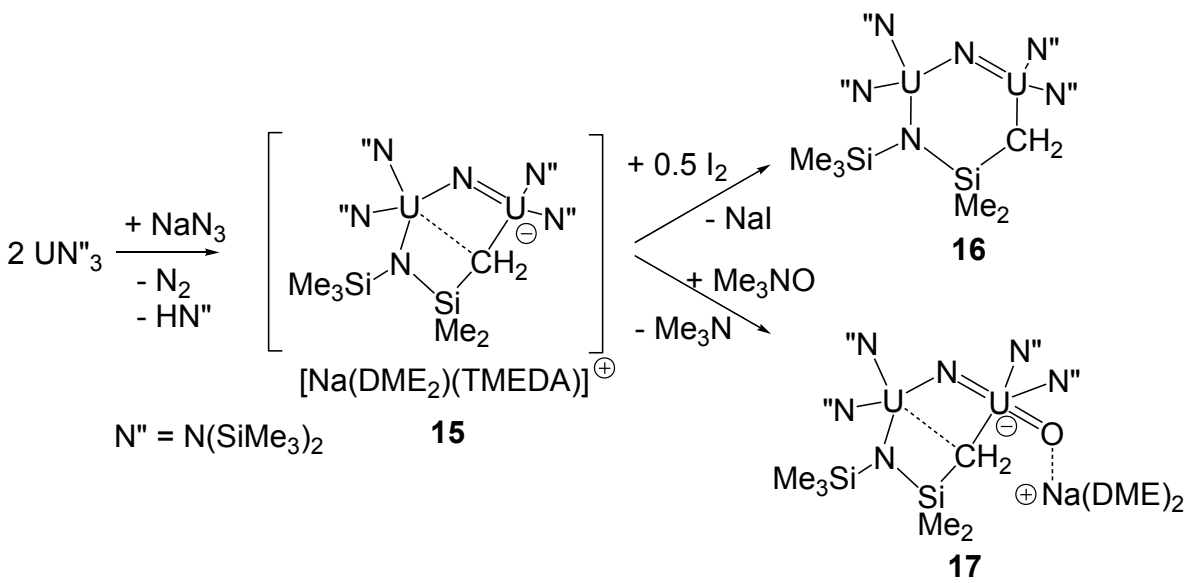

Scheme 8 - Synthesis of 15 - $17 .^{102}$

Despite reports of bis(imido) $(\mathrm{RN}=\mathrm{U}=\mathrm{NR})$ uranium complexes, ${ }^{103-105}$ derivatives of the uranyl analogue, in particular the $\left[\mathrm{NUO}^{+}\right.$ion, were not isolated and reported until 2010 by Hayton. A two-electron reduction of $\mathrm{NaN}_{3}$ by two equivalents of [ $\mathrm{UN}_{3}{ }_{3}$ ] generated the tetravalent species $\left[\mathrm{Na}(\mathrm{DME})_{2}(\mathrm{TMEDA})\right]\left[\left(\mathrm{N}_{2}{ }_{2}\right) \mathrm{U}(\mu-\mathrm{N})\left(\mathrm{CH}_{2} \mathrm{SiMe}_{2} \mathrm{NSiMe}_{3}\right) \mathrm{U}\left(\mathrm{N}^{\prime \prime}\right)_{2}\right]$ (15) (Scheme 8) in $69 \%$ yield. Although this reduction of azide was not unprecedented, the unexpected deprotonation of a methyl group yielded a $\mu-\mathrm{CH}_{2}$ group and liberated $\mathrm{HN}^{\prime \prime}$. The U-N $\mathrm{N}_{\text {nitride }}$ bond lengths (1.95(1) and 2.12(1) $\AA$ ), Figure 7, are not equivalent, which suggests localised $\mathrm{U}-\mathrm{N}=\mathrm{U}$ interactions which may be a result of the acute $\mathrm{U}-\mathrm{N}=\mathrm{U}$ bond angle of $123.5(5)^{\circ}$. Further oxidation to the neutral $\mathrm{U}^{(\mathrm{IV} / \mathrm{V})}$ complex $\left[\left(\mathrm{N}^{\prime \prime}{ }_{2}\right) \mathrm{U}(\mu-\right.$ $\left.\mathrm{N})\left(\mathrm{CH}_{2} \mathrm{SiMe}_{2} N \mathrm{SiMe}_{3}\right) \mathrm{U}\left(\mathrm{N}^{\prime \prime}\right)_{2}\right](\mathbf{1 6})$ with iodine revealed an even greater separation in U$\mathrm{N}_{\text {nitride }}$ distances of 1.909(6) and 2.201(6) $\AA$, Figure 8, providing additional evidence for localised bonding. The reaction of $\mathbf{1 5}$ with $\mathrm{Me}_{3} \mathrm{NO}$ produced the $\mathrm{U}^{\mathrm{VI}}$ mono-oxo complex $\left[\mathrm{Na}(\mathrm{DME})_{2}\right]\left[\left(\mathrm{N}^{\prime \prime}\right)_{2}(\mathrm{O}) \mathrm{U}(\mu-\mathrm{N})\left(\mathrm{CH}_{2} \mathrm{SiMe}_{2} \mathrm{NSiMe}_{3}\right) \mathrm{U}\left(\mathrm{N}^{\prime \prime}\right)_{2}\right](\mathbf{1 7})$ in $84 \%$ yield, Scheme 8. The sodium capped oxo ligand coordinated trans to the nitride ligand is reminiscent of the $[\mathrm{O}=\mathrm{U}=\mathrm{N}]^{+}$cation and provides evidence for the high degree of multiple bonding $\mathrm{U}^{\mathrm{VI}}$ can offer. The complex exhibits a U-O bond distance of 1.797(7) $\AA$ and a contracted $\mathrm{U}^{\mathrm{VI}}$ $\mathrm{N}_{\text {nitride }}$ bond length of 1.818(9) $\AA$, Figure 9. In contrast, the $\mathrm{U}^{\mathrm{IV}}-\mathrm{N}_{\text {nitride }}$ bond lengthens to 2.284(8) $\AA$ and is thus $0.47 \AA$ longer than $\mathrm{U}^{\mathrm{VI}}-\mathrm{N}_{\text {nitride }}$ distance supporting the localised bonding proposal. Investigations into possible magnetic coupling between the uranium 
centres in 15 and 16 using SQUID magnetometry revealed no observable communication which is likely due to the localised bonding scheme. ${ }^{102}$

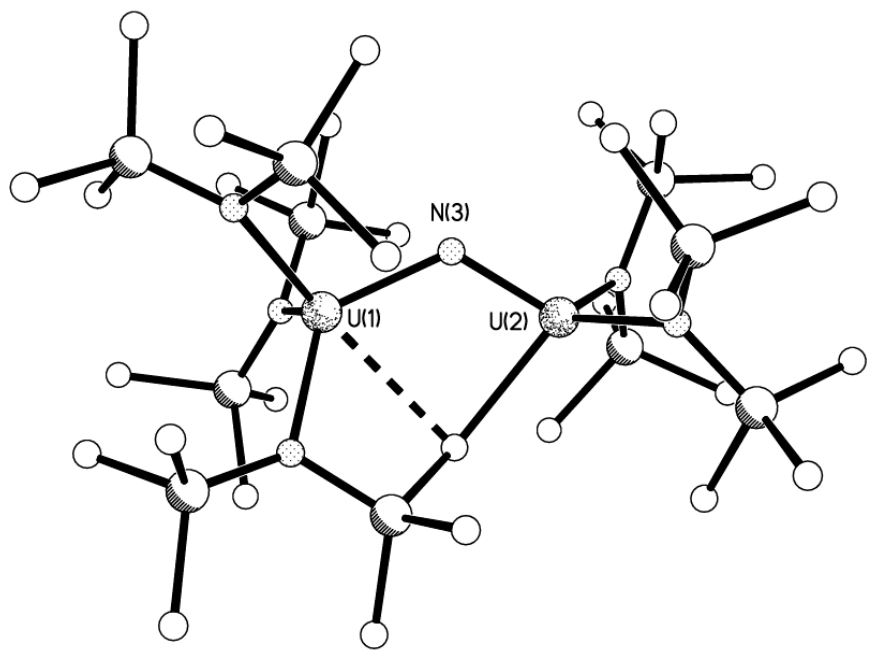

Figure 7 - Molecular structure of $\left[\mathrm{Na}(\mathrm{DME})_{2}(\mathrm{TMEDA})\right]\left[\left(\mathrm{N}^{\prime \prime}{ }_{2}\right) \mathrm{U}(\mu-\mathrm{N})\left(\mathrm{CH}_{2} \mathrm{SiMe}_{2} \mathrm{NSiMe}_{3}\right) \mathrm{U}\left(\mathrm{N}^{\prime \prime}\right)_{2}\right], 15$. Hydrogen atoms and cationic component are omitted for clarity.

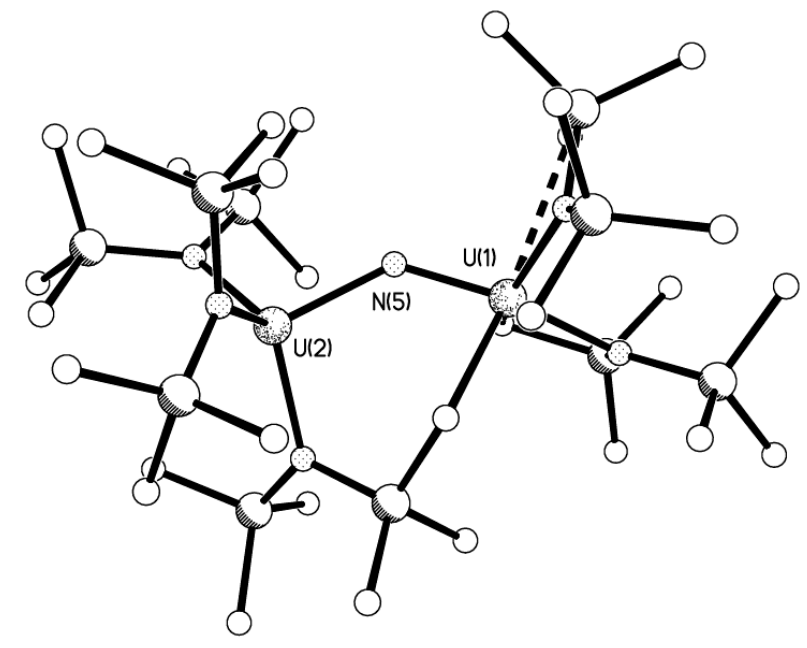

Figure 8 - Molecular structure of $\left[\left(\mathrm{N}_{2}{ }_{2}\right) \mathrm{U}(\mu-\mathrm{N})\left(\mathrm{CH}_{2} \mathrm{SiMe}_{2} \mathrm{NSiMe}_{3}\right) \mathrm{U}\left(\mathrm{N}^{\prime \prime}\right)_{2}\right], 16$. Hydrogen atoms are omitted for clarity. 


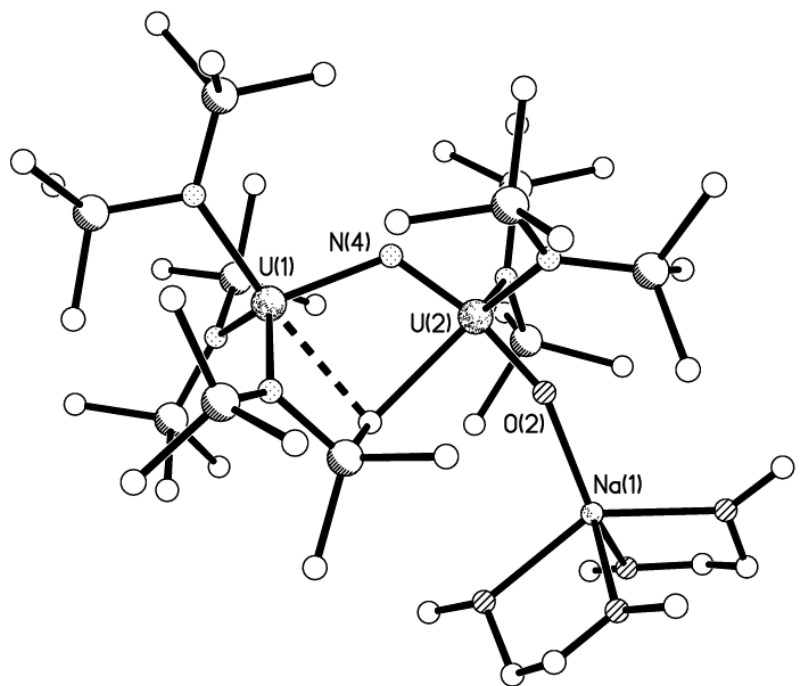

Figure 9 - Molecular structure of $\left[\mathrm{Na}(\mathrm{DME})_{2}\right]\left[\left(\mathrm{N}^{\prime \prime}\right)_{2}(\mathrm{O}) \mathrm{U}(\mu-\mathrm{N})\left(\mathrm{CH}_{2} \mathrm{SiMe}_{2} \mathrm{NSiMe}_{3}\right) \mathrm{U}\left(\mathrm{N}^{\prime \prime}\right)_{2}\right], 17$. Hydrogen atoms are omitted for clarity.

\subsection{Photochemically Generated Uranium Nitrides}

The decomposition of azide complexes via photolysis has proved an advantageous route towards transition metal nitrido complexes, ${ }^{106-108}$ however initial investigations into the photolysis of uranium azides did not result in activation of the azide group. ${ }^{109}$ In 2010 Kiplinger, Batista and co-workers reported the photolysis of a series of tetravalent terminal uranium azide complexes, Scheme 9, prepared using a gold azide transfer reagent. ${ }^{110,111}$ In the case of $\left[\mathrm{Cp}^{*}{ }_{2} \mathrm{U}\left(\mathrm{N}_{3}\right)(\mathrm{NR})\right]\left[\mathrm{R}=\mathrm{NPh}_{2}, \mathrm{O}\left(2,6{ }^{i}{ }^{i} \mathrm{Pr}_{2} \mathrm{C}_{6} \mathrm{H}_{3}\right)\right]$ photolysis led to decomposition or unidentifiable products. In contrast, photolysis of $\left[\mathrm{Cp}_{2}{ }_{2} \mathrm{U}\left(\mathrm{N}_{3}\right)\left(\mathrm{N}^{\prime \prime}\right)\right]$ (18) resulted in the isolation of the mixed amide complex $\left[\mathrm{Cp}^{*}\left(\mathrm{C}_{5} \mathrm{Me}_{4} \mathrm{CH}_{2} \mathrm{NH}\right) \mathrm{U}\left(\mathrm{N}^{\prime \prime}\right)\right]$ (19) (Scheme 9 and Figure 10). ${ }^{112}$ The decomposition of azide upon photolysis was observed by IR spectroscopy with the subsequent growth of an N-H band. The complex exhibits a U-NH bond length of 2.129(3) A consistent with reported $\mathrm{U}^{\mathrm{IV}}$ amide bond distances. ${ }^{113}$ 


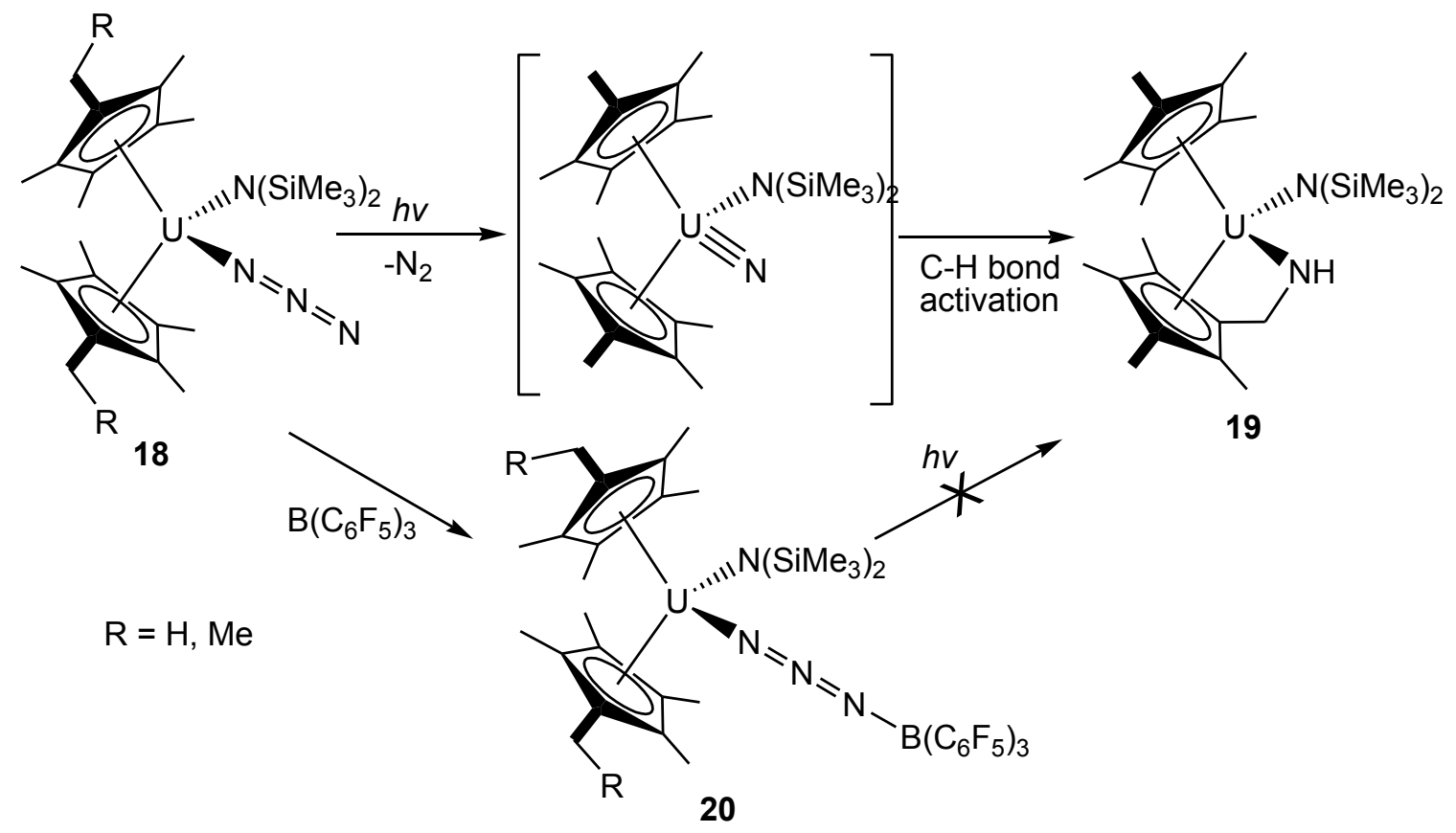

Scheme 9 - Synthesis of 19 and $20 .^{112}$

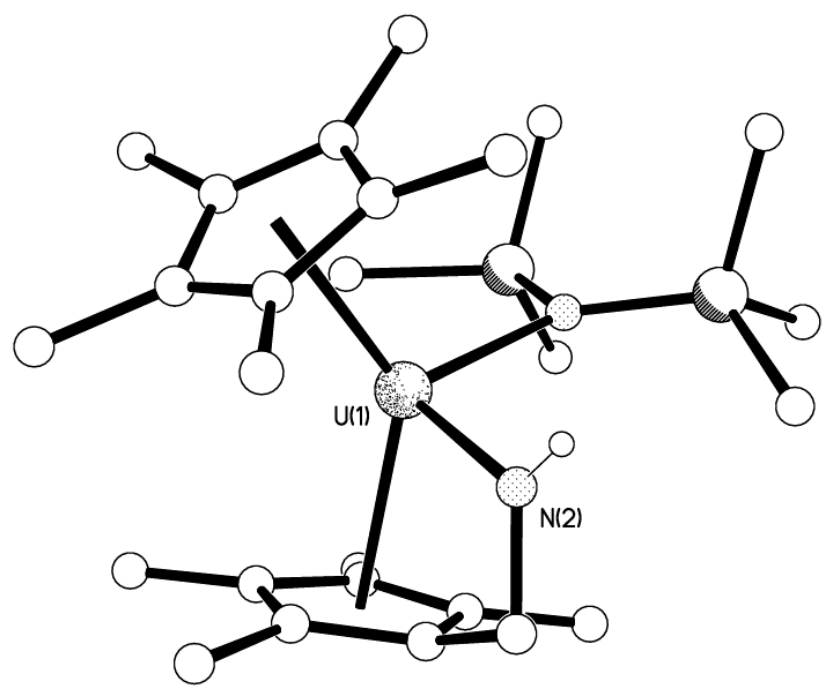

Figure 10 - Molecular structure of 19. Hydrogen atoms except for the amide hydrogen are omitted for clarity.

DFT calculations conducted on $\left[\mathrm{Cp}^{*}{ }_{2} \mathrm{U}\left\{\mathrm{N}\left(\mathrm{SiH}_{3}\right)_{2}\right\}\left(\mathrm{N}_{3}\right)\right]$ found the formation of $\left[\mathrm{Cp}^{*}\left(\mathrm{C}_{5} \mathrm{Me}_{4} \mathrm{CH}_{2} \mathrm{NH}\right) \mathrm{U}\left\{\mathrm{N}\left(\mathrm{SiH}_{3}\right)_{2}\right\}\right]$ was an exergonic process releasing $36.2 \mathrm{kcal} \mathrm{mol}^{-1}$ free energy. The decomposition of azide was found to be as a result of high energy MLCT transfer observed at $17500 \mathrm{~cm}^{-1}$ in the UV/vis/NIR spectrum between uranium and azide $\left(f \rightarrow \pi^{*}\right)$ leading to $\mathrm{N}_{2}$ loss and hexavalent uranium nitride formation. Selective 
irradiation UV/vis/NIR experiments confirmed the need of UV/vis photolysis rather than NIR, in promoting activation of the azide and the high energies required for reaction. The pathway by which $\mathrm{C}-\mathrm{H}$ activation occurs from nitride was investigated by DFT analysis of the possible intermediates. The lowest energy route was found to involve deprotonation of the methyl group by nucleophilic attack of the nitride unit to generate a $\mathrm{U}^{\mathrm{V}}$ imido transition state, followed by subsequent 1,2-migration of the methylene group to yield U-NH-C linkage, Scheme 10 . Formally the $\mathrm{U} \equiv \mathrm{N}$ linkage inserts into a $\mathrm{C}-\mathrm{H}$ bond in a 1,1-fashion. This type of nitride reactivity is unprecedented for f-element and transition metals yet reminiscent of cytochrome $\mathrm{P} 450$ oxidation of $\mathrm{C}-\mathrm{H}$ bonds to alcohols. The high reactivity and nucleophilicity of the nitride unit is exemplified by the low selectivity observed upon photolysis of analogous $\left[\left(\mathrm{Cp}^{\mathrm{Me}}{ }^{\mathrm{Et}}\right)_{2} \mathrm{U}\left(\mathrm{N}_{3}\right)\left(\mathrm{N}^{\prime \prime}\right)\right]$ which afforded a mixture of the possible products $\left[\left(\mathrm{Cp}^{\mathrm{Me} 4 \mathrm{Et}}\right)\left(\mathrm{C}_{5} \mathrm{Me}_{4} \mathrm{CH}_{2} \mathrm{CH}_{2} \mathrm{NH}\right) \mathrm{U}\left(\mathrm{N}^{\prime \prime}\right)\right]$ and $\left[\left(\mathrm{Cp}^{\mathrm{Me}_{4} \mathrm{Et}}\right)\left\{\mathrm{C}_{5}(\mathrm{Me})_{3}(\mathrm{Et})\left(\mathrm{CH}_{2} \mathrm{NH}\right)\right\} \mathrm{U}\left(\mathrm{N}^{\prime \prime}\right)\right]$. Attempts to trap the transient terminal uranium nitride using Lewis acidic capping groups such as $\mathrm{B}\left(\mathrm{C}_{6} \mathrm{~F}_{5}\right)_{3}$ were conducted. Photolysis of a 1:1 mixture of 18 and $\mathrm{B}\left(\mathrm{C}_{6} \mathrm{~F}_{5}\right)_{3}$ resulted in the isolation of the borane-capped azido species $\left[\left\{\mathrm{Cp}_{2}{ }_{2} \mathrm{U}\left(\mathrm{N}^{\prime \prime}\right)\right\}\left(\mu-\eta^{1}: \eta^{1} \mathrm{~N}_{3}\right)\left\{\mathrm{B}\left(\mathrm{C}_{6} \mathrm{~F}_{5}\right)_{3}\right\}\right]$ (20) which is photolytically inactive and can be reversibly converted back to $\mathbf{1 8}$ through dissolution in THF. This seminal work suggests terminal uranium nitrides are feasible, yet highly reactive.

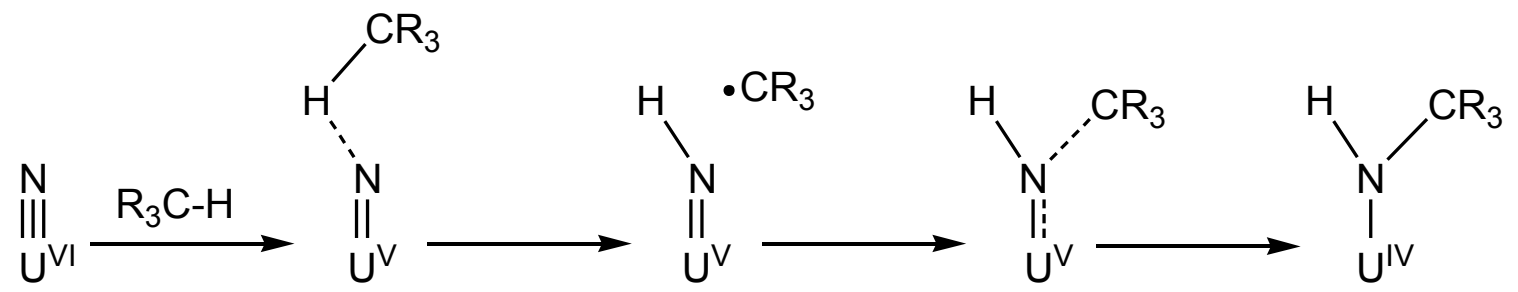

Scheme 10 - C-H activation pathway of uranium(VI) nitride. ${ }^{112}$

\subsection{Terminal Uranium Nitrides}

Recent work reported by Liddle has described the isolation of the terminal uranium nitride linkage for the first time utilising a highly sterically encumbered ligand framework, Scheme 11. In a two-electron redox reaction, treatment of [U(Tren $\left.\left.{ }^{\mathrm{TISS}}\right)\right]$ (21) $\left(\right.$ Tren $\left.^{\text {TIPS }}=N\left(\mathrm{CH}_{2} \mathrm{CH}_{2} \mathrm{NSi}^{i} \mathrm{Pr}_{3}\right)_{3}\right)$ with $\mathrm{NaN}_{3}$ in pyridine afforded, following work up, the pentavalent dinuclear complex, $\left[\mathrm{U}(\mu-\mathrm{N})(\mu-\mathrm{Na})\left(\operatorname{Tren}^{\mathrm{TIPS}}\right)\right]_{2}(\mathbf{2 2}) .{ }^{114}$ The complex exhibits 
a relatively short U- $\mathrm{N}_{\text {nitride }}$ bond length of 1.883(4) $\AA$, and the nitride groups are mutually stabilised by bridging sodium cation interactions. The observed ${ }^{14} \mathrm{~N} /{ }^{15} \mathrm{~N}$ isotopomer shift for the $\mathrm{U} \equiv \mathrm{N}$ IR band from 955 to $930 \mathrm{~cm}^{-1}$ (calculated shift $925 \mathrm{~cm}^{-1}$ ), supports the nitride source and formulation. Sequestration and encapsulation of the sodium cations through straightforward addition of two equivalents of 12C4 (12-crown-4) to 22 yielded the first uncapped terminal uranium(V) nitride complex, $\left[\mathrm{U}(\mathrm{N})\left(\operatorname{Tren}^{\mathrm{TIPS}}\right)\right]\left[\mathrm{Na}(12 \mathrm{C} 4)_{2}\right]$ (23) (Scheme 11). An X-ray diffraction study conducted on the complex revealed a U$\mathrm{N}_{\text {nitride }}$ bond length of $1.825(15) \AA$ in the terminal complex, Figure 11, which is $\sim 0.06 \AA$ shorter than in the bridging species. IR isotopic labelling studies $\left(\mathrm{UN}=936 \mathrm{~cm}^{-1}, \mathrm{U}^{15} \mathrm{~N}=\right.$ $900 \mathrm{~cm}^{-1}$ ), electronic absorption spectroscopy, and magnetic measurements support the formulation.

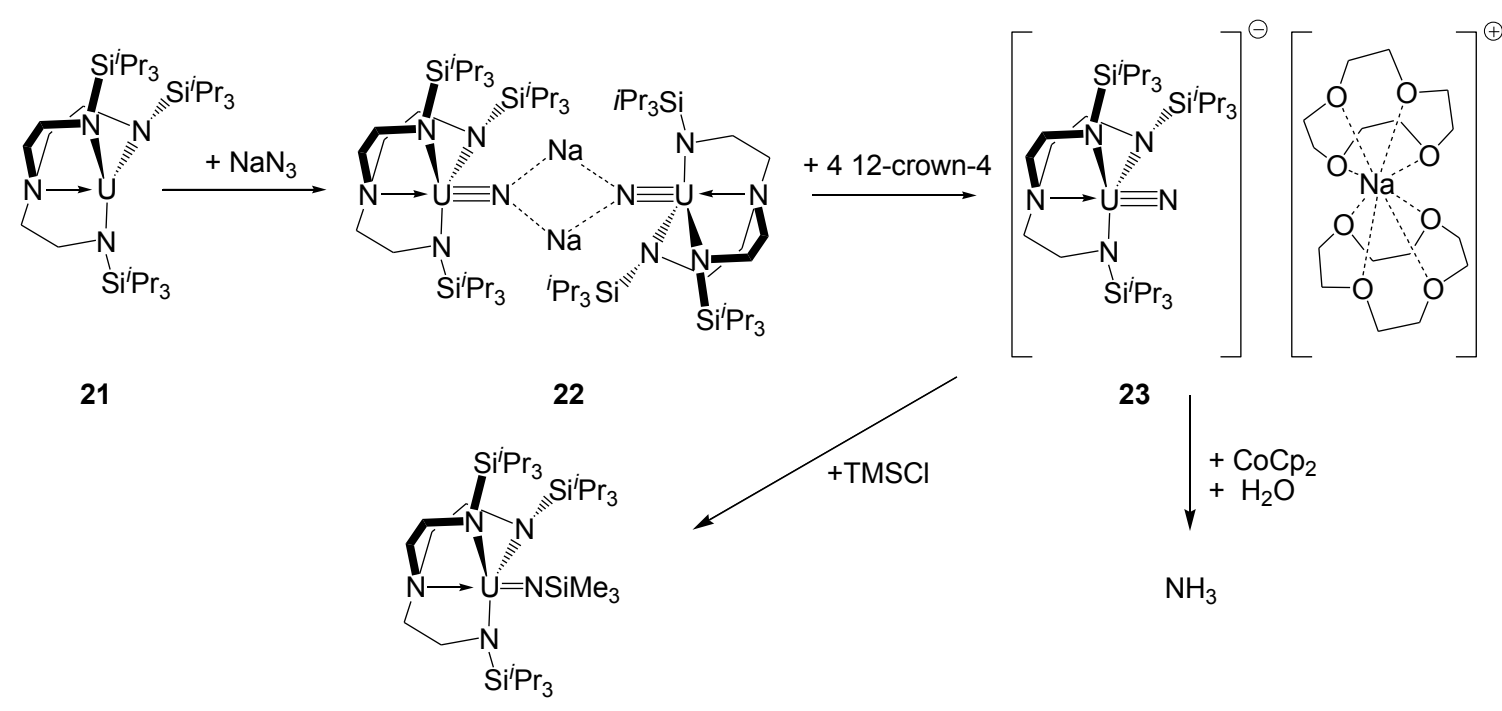

24

Scheme 11 - Synthesis of 22 and $24 .^{114}$

DFT calculations demonstrated that the HOMO-1, -2 and -3 represent significant $\mathrm{U} \equiv \mathrm{N}$ interactions in which one $\sigma$ - and two $\pi$-components are present. The $\sigma$ interaction is higher in energy than the quasi-degenerate $\pi$ components with similar MO ordering to the uranyl dication, ${ }^{115}$ but the reverse of $\mathrm{U}=\mathrm{C}$ and $\mathrm{U}=\mathrm{N}$ bonding manifolds. NBO analysis revealed significant uranium contributions to the $\sigma$ - and $\pi$-components (32 and $27 \%$, respectively) and significant participation of the $5 \mathrm{f}$ orbitals (44 and $72 \%$, respectively) 
with variable $6 \mathrm{~d}$ contributions (47 and 28\%, respectively) and a Mayer bond index of 2.91 was calculated for the $\mathrm{U} \equiv \mathrm{N}$ triple bond. Preliminary studies into the reactivity of the nitrido unit have also been conducted. Treatment of 23 with $\mathrm{Me}_{3} \mathrm{SiCl}$ yielded the pentavalent terminal imido uranium species $\left[\mathrm{U}\left(=\mathrm{NSiMe}_{3}\right)\left(\operatorname{Tren}^{\mathrm{TIPS}}\right)\right](\mathbf{2 4})$, Scheme 11, which could be prepared independently from 21 and $\mathrm{Me}_{3} \mathrm{SiN}_{3}$, which suggests a nucleophilic nitride that contrasts to the reactivity observed for 13. Notably, 23 decomposes in ethereal solvents which is consistent with the previous paucity of terminal uranium nitrides. Also, addition of $\mathrm{H}_{2} \mathrm{O}$ under reducing conditions liberated ammonia confirming a basic nitride functionality.

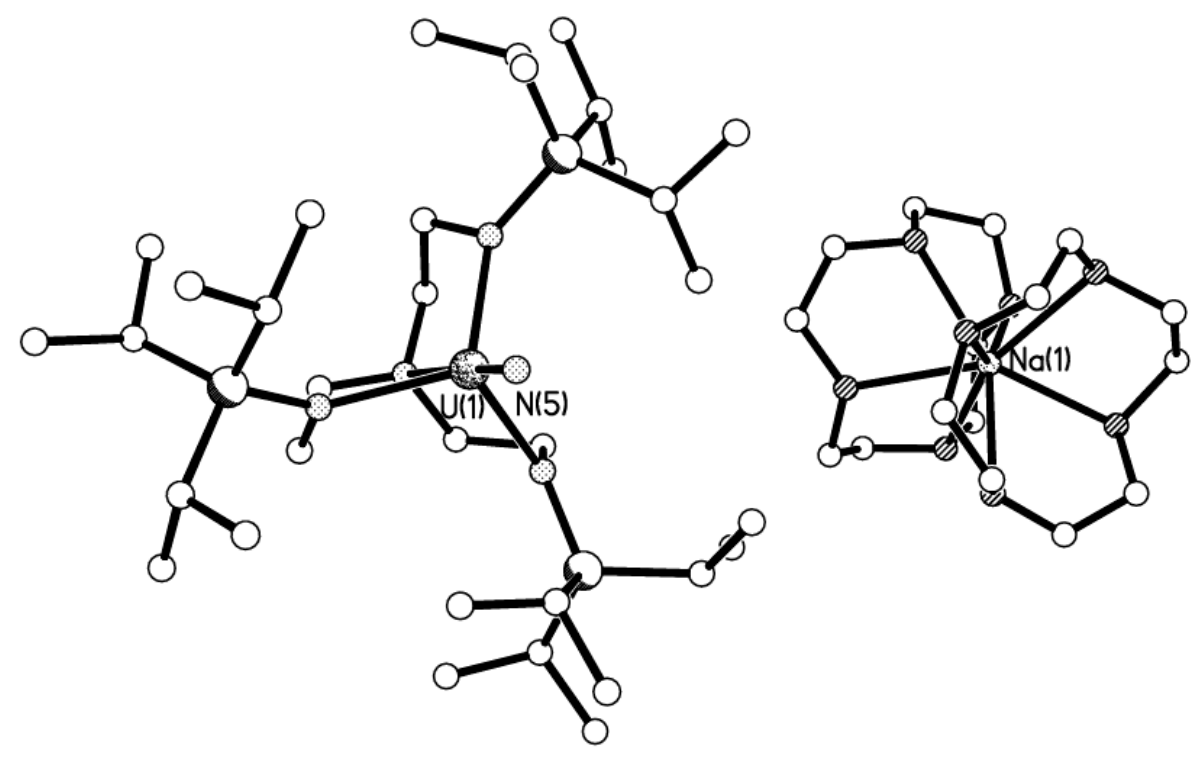

Figure 10- Molecular structure of 23. Hydrogen atoms are omitted for clarity. 

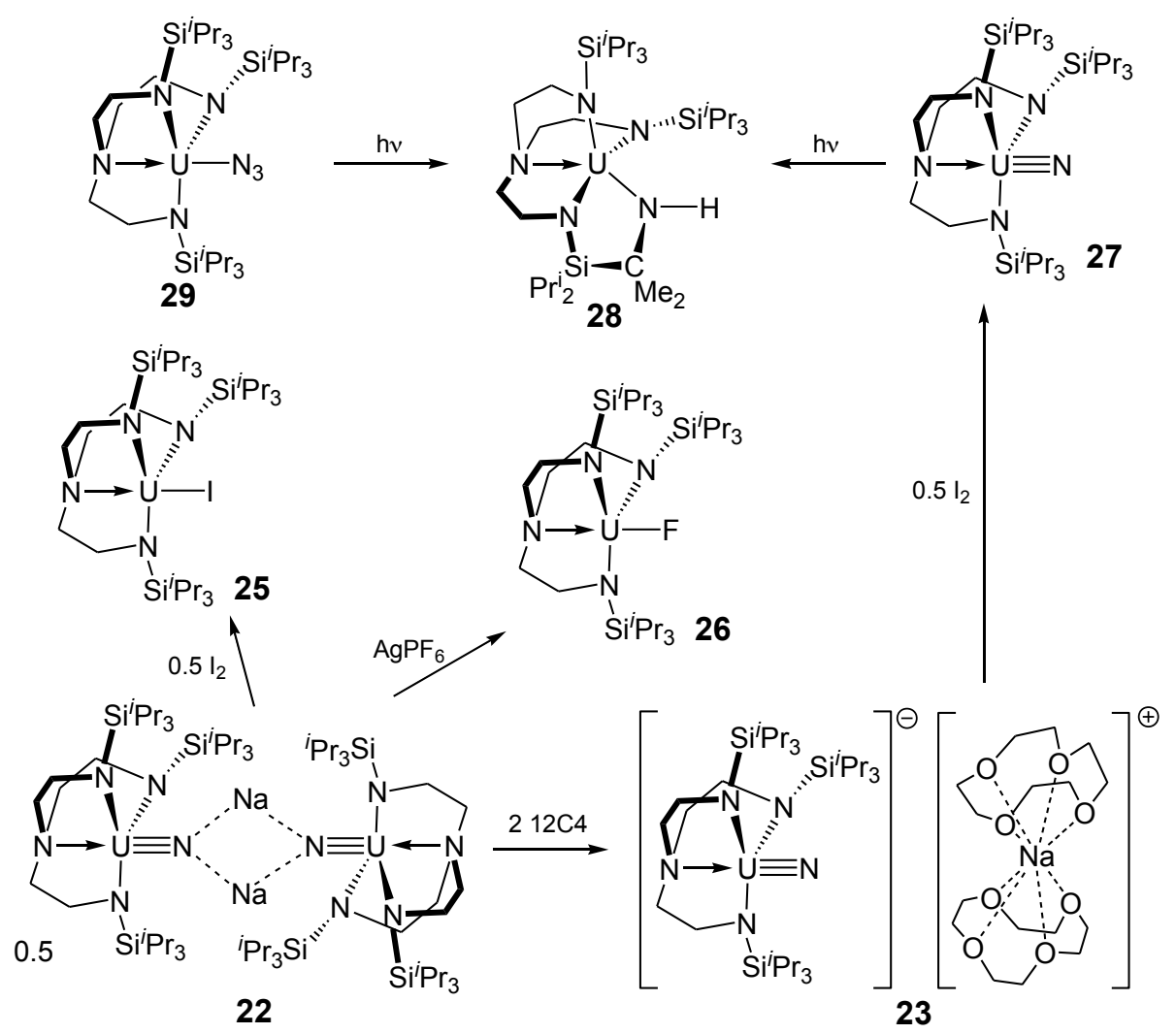

Scheme 12 - Synthesis of 25-29. ${ }^{116}$

Very recently, Liddle has reported the isolation of a terminal uranium(VI) nitride, Scheme 12. ${ }^{116}$ Initial attempts to oxidise 22 with mild oxidants such as iodine or $\mathrm{AgPF}_{6}$ resulted in loss of the nitride linkage and the formation of uranium(IV)-iodide or fluoride derivatives $\mathbf{2 5}$ and $\mathbf{2 6}$ as the only isolable species. However, treatment of $\mathbf{2 3}$ with iodine resulted in clean oxidation and after removal of the $\left[\mathrm{Na}(12 \mathrm{C} 4)_{2}\right][\mathrm{I}]$ by-product afforded $\left[\mathrm{U}(\mathrm{N})\left(\operatorname{Tren}^{\mathrm{TIPS}}\right)\right] \mathbf{2 7}$. The IR spectrum of 27 exhibits a $\mathrm{U} \equiv \mathrm{N}$ stretch at $914 \mathrm{~cm}^{-1}$ ( $883 \mathrm{~cm}^{-1}$ for the $\mathrm{U}^{15} \mathrm{~N}$ isotopomer; calculated shift to $885 \mathrm{~cm}^{-1}$ ) which compares well to 23 (Table 1). The $\mathrm{U}-\mathrm{N}_{\text {nitride }}$ bond length of 1.799(7) $\AA$, Figure 12, is now very short but is only modestly contracted compared to $\mathbf{2 3}(1.825(15) \AA$ ) which may reflect the fact that a non-bonding 5 f-electron is removed upon oxidation. 


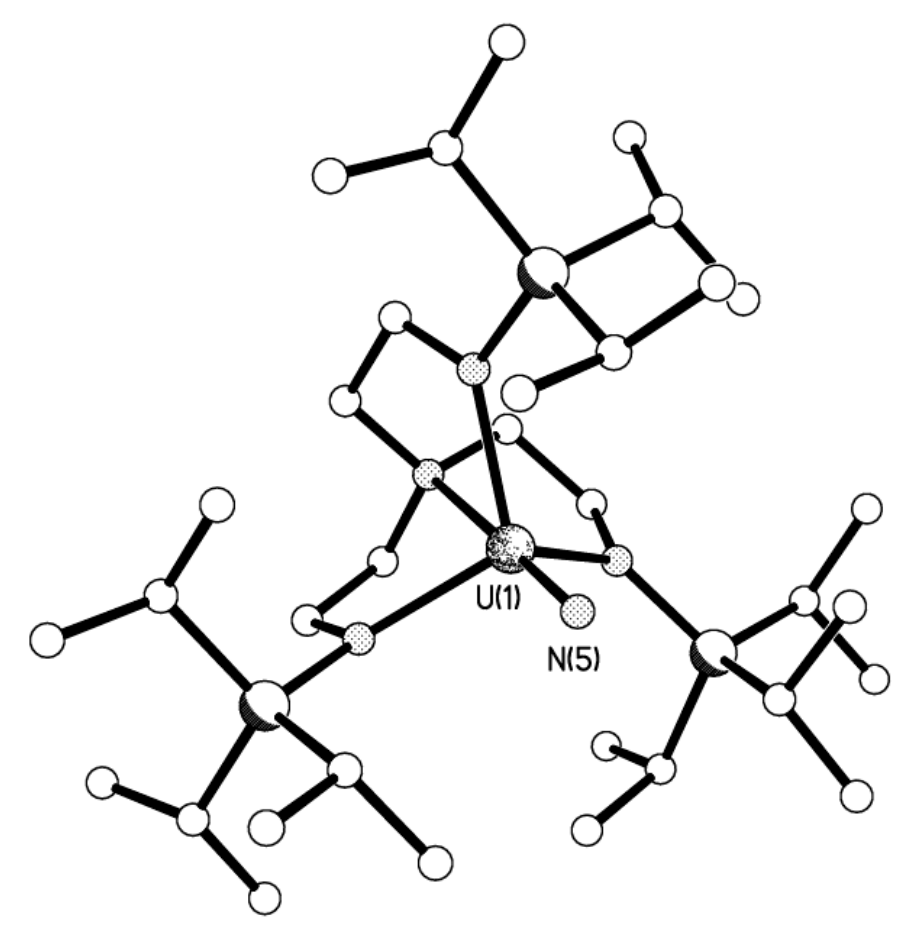

Figure 12 - Molecular structure of 27. Hydrogen atoms are omitted for clarity.

Interestingly, $\mathbf{2 7}$ is less stable than $\mathbf{2 3}$, and in solution $\mathbf{2 7}$ was found to convert into the cyclometallated, $\mathrm{C}-\mathrm{H}$ activated product $\mathbf{2 8}$ in a reaction that is analogous to the chemistry that produces 19 reported by Kiplinger and Batista. ${ }^{112}$ The conversion of $\mathbf{2 7}$ into 28 was found to be promoted by strong sunlight $\left(t_{1 / 2} \sim 7\right.$ days) but accelerated by photolysis using a $125 \mathrm{~W}$ medium-pressure mercury lamp to be complete in 20 minutes at room temperature. This experimentally corroborates the computational proposal of Kiplinger and Batista that $\mathbf{1 9}$ is produced from a transiently formed nitride intermediate. Indeed, the formation of 28 suggests an important reason for the prior absence of terminal uranium(VI) nitrides since photolysis of an azide to nitride functional group was a previously identified strategy for producing a uranium nitride. In-line with this, photolysis of compound 29 results in clean conversion to $\mathbf{2 8}$. It is thus concluded that photolysis of uranium azides can produce uranium nitrides, but under photolytic conditions subsequent $\mathrm{C}-\mathrm{H}$ activation and insertion occurs to afford amide derivatives. In contrast, photolysis of $\mathbf{2 3}$ does not result in amide formation, which demonstrates the greater stability of the uranium(V) nitride linkage over the uranium(VI) nitride linkage. 
This is entirely consistent with the mechanism in Scheme 10 since the first step after azide conversion to nitride is facile electron transfer to uranium which would be favoured for uranium(VI) over uranium(V) since the former is more oxidising than the latter.

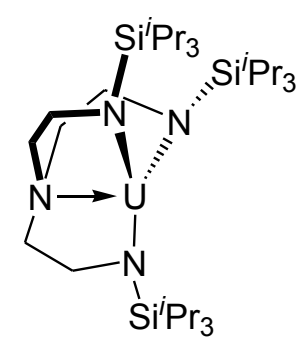

21

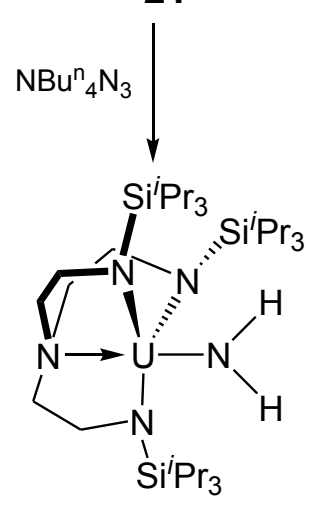

30

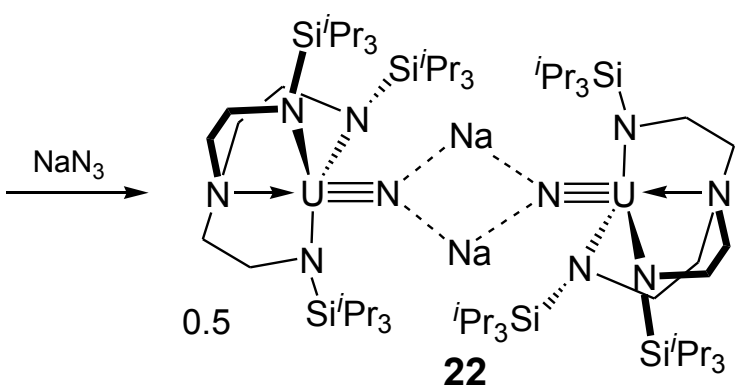

22

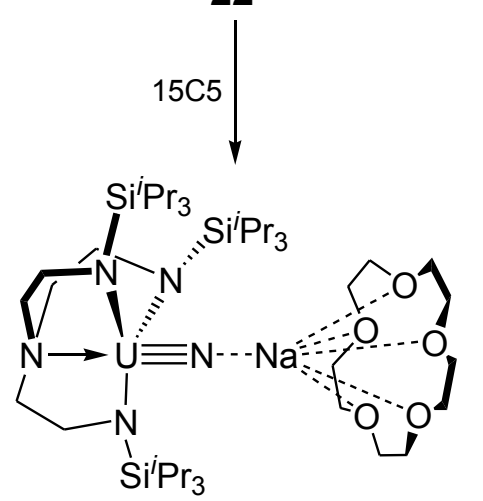

31

Scheme 13 - Synthesis of 30 and 31. ${ }^{116}$

The recent isolation of uranium(V) and (VI) nitrides raised several questions about why the $\mathrm{U} \equiv \mathrm{N}$ linkage had been so elusive and Liddle has reported reactivity data which provide some explanations. It is clear that a very bulky ancillary ligand was required that provided a pocket for azide to react with $\mathbf{2 1}$, yet was sterically demanding enough to prevent the newly installed nitride bridging to another uranium centre as observed, for example, in 10-17. The presence of a stabilising sodium ion in the synthesis of 22 would appear to be key since when $\mathbf{2 1}$ is treated with $\left[{ }^{n} \mathrm{Bu}_{4} \mathrm{~N}\right]\left[\mathrm{N}_{3}\right]$ the primary amido complex 30 is formed, Scheme 13 and Figure 13. This suggests a nitride is formed transiently, but without the electrostatic stabilisation provided by sodium during installation the nitride reacts with solvent; this was confirmed by a deuterium labelling study which confirmed the two amide hydrogen atoms in $\mathbf{3 0}$ originate from the toluene solvent of reaction. 

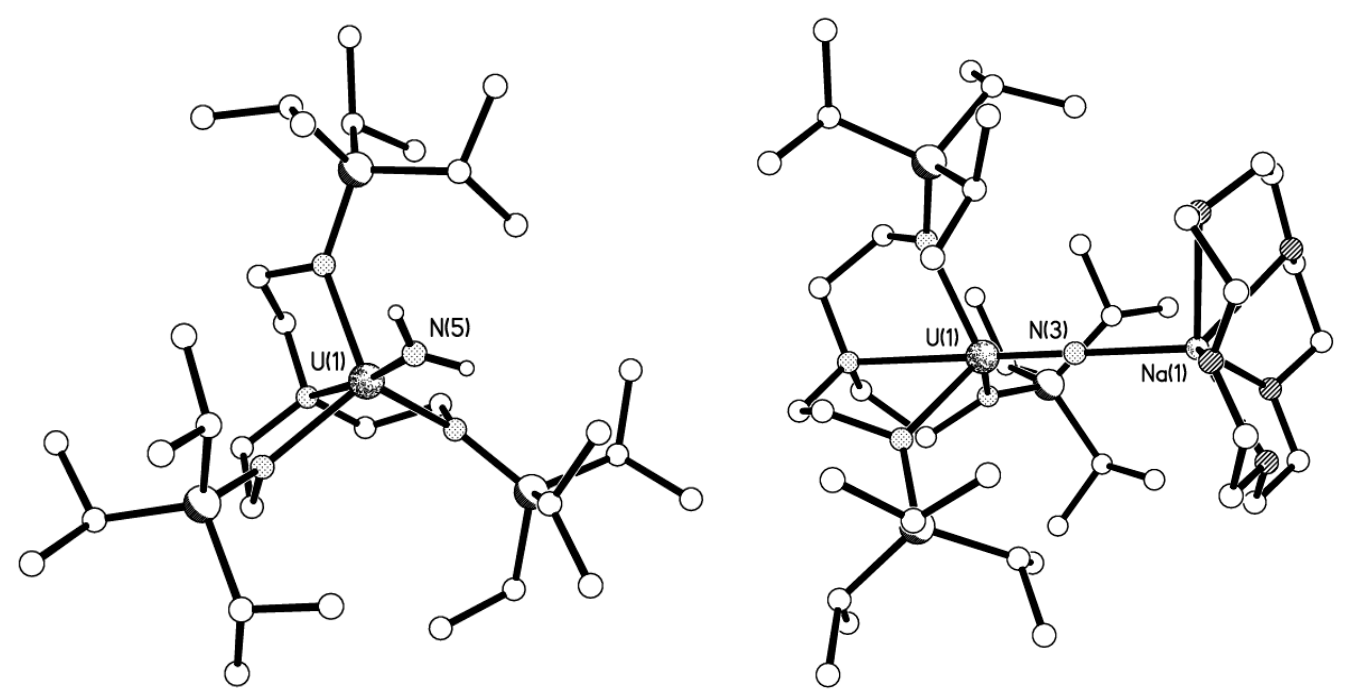

Figure 13 - Structures of 30 and 31. Hydrogen atoms are omitted for clarity.

The abstraction of the sodium ions was also investigated. Whereas covalently bound boranes (cf 10-14, 19) and trimethylsilyl groups (cf 24) remain impervious to removal from the nitride functional group, the electrostatically bonded sodium ions in $\mathbf{2 2}$ can be sequestered by $12 \mathrm{C} 4$ to give $\mathbf{2 3}$. However, it was reported that a range of crown ethers and cryptands fail to abstract the sodium ions from 22, which presents further evidence of the nucleophilic nature of the terminal uranium nitride linkage, and treating 22 with $15 \mathrm{C} 5$ (15-crown-5 ether) results in the monomeric complex $\mathbf{3 1}$ where the nitride is still coordinated to sodium, Scheme 13 and Figure 13. Crystallographic analysis of complex 31 showed a U-N $\mathrm{N}_{\text {nitride }}$ bond length of 1.810(5) $\AA$ which is surprisingly similar to $\mathbf{2 3}$ and 27. The characterisation data for $\mathbf{3 1}$ support the pentavalent formulation, and the IR data show a UN stretch at $856 \mathrm{~cm}^{-1}$ which is reduced to $827 \mathrm{~cm}^{-1}$ for the ${ }^{15} \mathrm{~N}$-isotopomer (reduced mass calculation predicts $829 \mathrm{~cm}^{-1}$ ). Thus, the identity of the sodium sequestering agent appears to be a key factor in the successful isolation of a terminal uranium nitride. The isolation of $\mathbf{2 7}$ from $\mathbf{2 3}$ but not $\mathbf{2 2}$ shows that the method of oxidation is important, and the stability of uranium(V) vs (VI) nitrides shows that the oxidation state of uranium has a profound effect on the stability of the terminal uranium nitride linkage. 
These recent advances have enabled a computational assessment of the nature of the uranium nitride bond. Computational analysis of 27 is surprising inasmuch as there is very little variation in the composition of the $\mathrm{U} \equiv \mathrm{N}$ triple bond between the (V) and (VI) oxidation states of uranium. However, a consistent theme is that the $\sigma$-component is always higher than the $\pi$-components for nitrides, as is the case for uranyl, whereas the corresponding imido complexes follow the normal energetic ordering of $\pi>\sigma$ as is the case for $\mathrm{U}=\mathrm{C}$ double bonds. This energetic ordering is proposed to occur in nitrides due the unusually short U-N distance manifesting an antibonding interaction between a $\sigma$ orientated nitrogen p-orbital overlapping with the toroidal $5 \mathrm{f}$ and $6 \mathrm{~d}$ lobes on uranium. A QTAIM study of these nitrides and isovalent group 6 nitrides suggested the surprising conclusion that the levels of covalency in uranium nitride bonds is of similar, if not greater, magnitude to group 6 nitrides.

\section{Summary and Outlook}

It is clear that the field of uranium nitride chemistry is now burgeoning. After elegant matrix isolation experiments and computational characterisation methods led the way, and threw down the gauntlet to the synthetic actinide community, significant advances in uranium nitride chemistry have been made in the last decade or so. Many molecular bridging uranium nitrides have now been isolated and thoroughly characterised. More recently, the first terminal uranium(V) and (VI) nitrides have at long last been secured. These advances have provided significant insights into the bonding of the $U \equiv N$ triple bond suggesting that a rich seam of novel reactivity is awaiting discovery. Several questions now present themselves. What is the scope of ligand-sets that can stabilise uranium nitride linkages? Can terminal uranium nitrides with uranium in the (III) and (IV) oxidation states be isolated? Given the novel reactivity and magnetism that can be supported by Tren-uranium complexes, ${ }^{88,117-120}$ what stoichiometric and catalytic reactivity might be achieved with terminal uranium nitride linkages? Given the patent for Haber Bosch ammonia synthesis mentions uranium and uranium nitrides as efficient promoters of ammonia formation, ${ }^{121}$ what relevance do the molecular systems described herein have to their heterogeneous congeners? Could molecular systems such as the ones 
described herein constitute useful low-temperature precursors to uranium nitride materials? Further research into this area in order to fully understand the nature of the $\mathrm{U} \equiv \mathrm{N}$ triple bond is surely warranted.

\section{Acknowledgements}

The Authors are grateful for continued and generous support by the Royal Society, European Research Council, UK Engineering and Physical Sciences Research Council, University of Nottingham, UK National Nuclear Laboratories, and European Cooperation in Science and Technology.

\section{References}

1. M. B. Jones and A. J. Gaunt, Chem. Rev. 113 (2013) 1137-1198.

2. B. Baker, Chem. Eur. J. 18 (2012) 16258-16271.

3. T. W. Hayton, Dalton Trans. 39 (2010) 1145-1158.

4. T. W. Hayton, Chem Commun. 49 (2013) 2956-2973.

5. R. A. Andersen, Inorg. Chem. 18 (1979) 1507-1509.

6. P. Roussel, R. Boaretto, A. J. Kingsley, N. W. Alcock and P. Scott, J. Chem. Soc., Dalton. Trans. (2002) 1423-1428.

7. W. J. Evans, S. A. Kozimor and J. W. Ziller, Polyhedron 23 (2004) 2689-2694.

8. G. Zi, L. Jia, E. L. Werkema, M. D. Walter, J. P. Gottfriedsen and R. A. Andersen, Organometallics 24 (2005) 4251-4264.

9. S. C. Bart, C. Anthon, F. W. Heinemann, E. Bill, N. M. Edelstein and K. Meyer, J. Am. Chem. Soc. 130 (2008) 12536-12546.

10. S. J. Kraft, J. Walensky, P. E. Fanwick, M. B. Hall and S. C. Bart, Inorg. Chem. 49 (2010) 7620-7622.

11. S. Fortier, N. Kaltsoyannis, G. Wu and T. W. Hayton, J. Am. Chem. Soc. 133 (2011) 14224-14227.

12. J. L. Brown, S. Fortier, R. A. Lewis, G. Wu and T. W. Hayton, J. Am. Chem. Soc. 134 (2012) 15468-15475.

13. S. Fortier, J. L. Brown, N. Kaltsoyannis, G. Wu and T. W. Hayton, Inorg. Chem. 51 (2012) 1625-1633. 
14. B. Kosog, H. S. La Pierre, F. W. Heinemann, S. T. Liddle and K. Meyer, J. Am. Chem. Soc. 134 (2012) 5284-5289.

15. R. A. Andersen and J. G. Brennan, J. Am. Chem. Soc. 107 (1985) 514-516.

16. P. C. Blake, M. F. Lappert, R. G. Taylor, J. L. Atwood and H. Zhang, Inorg. Chim. Acta 139 (1987) 13-20.

17. R. E. Cramer, J. H. Jeong and J. W. Gilje, Organometallics 6 (1987) 2010-2012.

18. A. Zalkin, J. G. Brennan and R. A. Andersen, Acta Crystallogr., Sect. C 44 (1988) 1553-1554.

19. C. J. Burns, W. H. Smith, J. C. Huffman and A. P. Sattelberger, J. Am. Chem. Soc. 112 (1990) 3237-3239.

20. D. S. J. Arney, C. J. Burns and D. C. Smith, J. Am. Chem. Soc. 114 (1992) 1006810069.

21. D. S. J. Arney and C. J. Burns, J. Am. Chem. Soc. 115 (1993) 9840-9841.

22. D. S. J. Arney and C. J. Burns, J. Am. Chem. Soc. 117 (1995) 9448-9841.

23. P. Roussel, P. B. Hitchcock, N. Tinker and P. Scott, Chem. Commun. (1996) 2053-2054.

24. B. P. Warner, B. L. Scott and C. J. Burns, Angew. Chem. Int. Ed. 37 (1998) 959960.

25. R. G. Peters, B. P. Warner and C. J. Burns, J. Am. Chem. Soc. 121 (1999) 55855586.

26. I. Castro-Rodriguez, K. Olsen, P. Gantzel and K. Meyer, J. Am. Chem. Soc. 125 (2003) 4565-4571.

27. W. J. Evans, S. A. Kozimor and J. W. Ziller, Chem. Commun. (2005) 4681-4683.

28. G. Zi, L. L. Blosch, L. Jia and R. A. Andersen, Organometallics 24 (2005) 46024612.

29. I. Castro-Rodriguez and K. Meyer, Chem. Commun. (2006) 1353-1368.

30. I. Castro-Rodríguez, H. Nakai and K. Meyer, Angew. Chem. Int. Ed. 45 (2006) 2389-2392.

31. C. R. Graves, B. L. Scott, D. E. Morris and J. L. Kiplinger, J. Am. Chem. Soc. 129 (2007) 11914-11915. 
32. C. R. Graves, E. J. Schelter, T. Cantat, B. L. Scott and J. L. Kiplinger, Organometallics 27 (2008) 5371-5378.

33. C. R. Graves, B. L. Scott, D. E. Morris and J. L. Kiplinger, Organometallics 27 (2008) 3335-3337.

34. C. R. Graves, A. E. Vaughn, E. J. Schelter, B. L. Scott, J. D. Thompson, D. E. Morris and J. L. Kiplinger, Inorg. Chem. 47 (2008) 11879-11891.

35. C. R. Graves, P. Yang, S. A. Kozimor, A. E. Vaughn, D. L. Clark, S. D. Conradson, E. J. Schelter, B. L. Scott, J. D. Thompson, P. J. Hay, D. E. Morris and J. L. Kiplinger, J. Am. Chem. Soc. 130 (2008) 5272-5285.

36. W. J. Evans, E. Montalvo, J. W. Ziller, A. G. DiPasquale and A. L. Rheingold, Inorg. Chem. 49 (2009) 222-228.

37. C. R. Graves, B. L. Scott, D. E. Morris and J. L. Kiplinger, Chem. Commun. (2009) 776-778.

38. I. Korobkov and S. Gambarotta, Inorg. Chem. 49 (2010) 3409-3418.

39. O. P. Lam, F. Heinemann and K. Meyer, C. R. Chimie 13 (2010) 803-811.

40. O. P. Lam, S. M. Franke, H. Nakai, F. W. Heinemann, W. Hieringer and K. Meyer, Inorg. Chem. 51 (2012) 6190-6199.

41. E. M. Matson, M. G. Crestani, P. E. Fanwick and S. C. Bart, Dalton Trans. 41 (2012) 7952-7958.

42. L. Ventelon, C. Lescop, T. Arliguie, P. Leverd, M. Lance, M. Nierlich and M. Ephritikhine, Chem. Commun. (1999) 659-660.

43. J. W. Gilje, R. E. Cramer, R. B. Maynard and J. C. Paw, J. Am. Chem. Soc. 103 (1981) 3589-3590.

44. R. E. Cramer, R. B. Maynard, J. C. Paw and J. W. Gilje, Organometallics 2 (1983) 1336-1340.

45. R. E. Cramer, M. A. Bruck, F. Edelmann, D. Afzal, J. W. Gilje and H. Schmidbaur, Chem. Ber. 121 (1988) 417-420.

46. T. Cantat, T. Arliguie, N. Noel, P. Thuery, M. Ephritikhine, P. Le Floch and N. Mezailles, J. Am. Chem. Soc. 131 (2009) 963-972.

47. O. J. Cooper, J. McMaster, W. Lewis, A. J. Blake and S. T. Liddle, Dalton Trans. 39 (2010) 5074-5076. 
48. J.-C. Tourneux, J. C. Berthet, P. Thuery, N. Mezailles, P. Le Floch and M. Ephritikhine, Dalton Trans. 39 (2010) 2494-2496.

49. O. J. Cooper, D. P. Mills, J. McMaster, F. Moro, E. S. Davies, W. Lewis, A. J. Blake and S. T. Liddle, Angew. Chem. Int. Ed. 50 (2011) 2383-2386.

50. S. Fortier, J. R. Walensky, G. Wu and T. W. Hayton, J. Am. Chem. Soc. 133 (2011) 6894-6897.

51. G. Ma, M. J. Ferguson, R. McDonald and R. G. Cavell, Inorg. Chem. 50 (2011) 6500-6508.

52. D. P. Mills, F. Moro, J. McMaster, S. J. van, W. Lewis, A. J. Blake and S. T. Liddle, Nat. Chem. 3 (2011) 454-460.

53. J.-C. Tourneux, J.-C. Berthet, T. Cantat, P. Thuery, N. Mezailles and M. Ephritikhine, J. Am. Chem. Soc. 133 (2011) 6162-6165.

54. J.-C. Tourneux, J.-C. Berthet, T. Cantat, P. Thuery, N. Mezailles, P. Le Floch and M. Ephritikhine, Organometallics 30 (2011) 2957-2971.

55. D. P. Mills, O. J. Cooper, F. Tuna, E. J. L. McInnes, E. S. Davies, J. McMaster, F. Moro, W. Lewis, A. J. Blake and S. T. Liddle, J. Am. Chem. Soc. 134 (2012) 10047-10054.

56. M. Ephritikhine, Dalton Trans. (2006) 2501-2516.

57. A. R. Fox, S. C. Bart and C. C. Cummins, Nature 455 (2008) 341-349.

58. B. J. Jaques, B. M. Marx, A. S. Hamdy and D. P. Butt, J. Nucl. Mater. 381 (2008) 309-311.

59. T. M. Besmann, D. Shin and T. B. Lindemer, J. Nucl. Mater. 427 (2012) 162-168.

60. L. Black, F. Miserque, T. Gouder, L. Havela, J. Rebizant and F. Wastin, J. Alloys Compnd. 315 (2001) 36-41.

61. G. W. C. Silva, C. B. Yeamans, A. P. Sattelberger, T. Hartmann, G. S. Cerefice and K. R. Czerwinski, Inorg. Chem. 48 (2009) 10635-10642.

62. Y. Arai, S. Fukushima, K. Shiozawa and M. Handa, J. Nucl. Mater. 168 (1989) 280-289.

63. S. K. Mukerjee, J. V. Dehadraya, V. N. Vaidya and D. D. Sood, J. Nucl. Mater. 185 (1991) 39-49. 
64. T. Ogawa, Y. Shirasu, K. Minato and H. Serizawa, J. Nucl. Mater. 247 (1997) 151-157.

65. K. Minato, M. Akabori, M. Takano, Y. Arai, K. Nakajima, A. Itoh and T. Ogawa, J. Nucl. Mater. 320 (2003) 18-24.

66. Y. Arai and K. Minato, J. Nucl. Mater. 344 (2005) 180-185.

67. M. Katsura and H. Serizawa, J. Alloys Compnd. 196 (1993) 191-197.

68. T. Nakagawa, H. Matsuoka, M. Sawa, M. Hirota, M. Miyake and M. Katsura, J. Nucl. Mater. 247 (1997) 127-130.

69. G. W. C. Silva, C. B. Yeamans, L. Ma, G. S. Cerefice, K. R. Czerwinski and A. P. Sattelberger, Chem. Mater. 20 (2008) 3076-3084.

70. D. W. Green and G. T. Reedy, J. Chem. Phys. 65 (1976) 2921-2922.

71. R. D. Hunt, J. T. Yustein and L. Andrews, J. Chem. Phys. 98 (1993) 6070-6074.

72. G. P. Kushto, P. F. Souter and L. Andrews, J. Chem. Phys. 108 (1998) 71217130.

73. P. Pyykkö, J. Li and N. Runeberg, J. Chem. Phys. 98 (1994) 4809-4813.

74. K. Sankaran, K. Sundararajan and K. S. Viswanathan, J. Phys. Chem. A 105 (2001) 3995-4001.

75. G. P. Kushto, P. F. Souter, L. Andrews and M. Neurock, J. Chem. Phys. 106 (1997) 5894-5903.

76. C. Heinemann and H. Schwarz, Chem. Eur. J. 1 (1995) 7-11.

77. M. Zhou and L. Andrews, J. Chem. Phys. 111 (1999) 11044-11049.

78. P. Pyykkö, J. Li and N. Runeberg, J. Phys. Chem. 98 (1994) 4809-4813.

79. $\quad$ N. Kaltsoyannis, Inorg. Chem. 39 (2000) 6009-6017.

80. L. Andrews, X. Wang, R. Lindh, B. O. Roos and C. J. Marsden, Angew. Chem. Int. Ed. 47 (2008) 5366-5370.

81. X. Wang, L. Andrews, B. Vlaisavljevich and L. Gagliardi, Inorg. Chem. 50 (2011) 3826-3831.

82. L. Gagliardi and P. Pyykkö, Inorg. Chem. 42 (2003) 3074-3078.

83. L. Gagliardi and P. Pyykkö, Angew. Chem. Int. Ed. 43 (2004) 1573-1576.

84. D. J. Mindiola and C. C. Cummins, Angew. Chem. Int. Ed. 37 (1998) 945-947. 
85. K. Meyer, D. J. Mindiola, T. A. Baker, W. M. Davis and C. C. Cummins, Angew. Chem. Int. Ed. 39 (2000) 3063-3066.

86. A. L. Odom, P. L. Arnold and C. C. Cummins, J. Am. Chem. Soc. 120 (1998) 5836-5837.

87. P. Roussel, N. D. Tinker and P. Scott, J. Alloys Compnd. 271-273 (1998) 150153.

88. P. Roussel and P. Scott, J. Am. Chem. Soc. 120 (1998) 1070-1071.

89. P. Roussel, W. Errington, N. Kaltsoyannis and P. Scott, J. Organomet. Chem. 635 (2001) 69-74.

90. F. G. N. Cloke and P. B. Hitchcock, J. Am. Chem. Soc. 124 (2002) 9352-9353.

91. W. J. Evans, S. A. Kozimor and J. W. Ziller, J. Am. Chem. Soc. 125 (2003) 14264-14265.

92. S. M. Mansell, N. Kaltsoyannis and P. L. Arnold, J. Am. Chem. Soc. 133 (2011) 9036-9051.

93. I. Korobkov, S. Gambarotta and G. P. A. Yap, Angew. Chem. Int. Ed. 41 (2002) 3433-3436.

94. W. J. Evans, S. A. Kozimor and J. W. Ziller, Science, 309 (2005) 1835-1838.

95. W. J. Evans, K. A. Miller, J. W. Ziller and J. Greaves, Inorg. Chem. 46 (2007) 8008-8018.

96. C. P. Larch, F. G. N. Cloke and P. B. Hitchcock, Chem. Commun. (2008) 82-84.

97. T. K. Todorova, L. Gagliardi, J. R. Walensky, K. A. Miller and W. J. Evans, J. Am. Chem. Soc.132 (2010) 12397-12403.

98. N. Nocton, J. Pecaut and M. Mazzanti, Angew. Chem. Int. Ed. 47 (2008) 30403042.

99. A. Fox and C. Cummins, J. Am. Chem. Soc. 131 (2009) 5716-5717.

100. A. R. Fox, P. L. Arnold and C. C. Cummins, J. Am. Chem. Soc. 132 (2010) 32503251.

101. D. J. Mindiola, Y.-C. Tsai, R. Hara, Q. Chen, K. Meyer and C. C. Cummins, Chem. Commun. (2001) 125-126.

102. S. Fortier, G. Wu and T. W. Hayton, J. Am. Chem. Soc. 132 (2010) 6888-6889. 
103. T. W. Hayton, J. M. Boncella, B. L. Scott, P. D. Palmer, E. R. Batista and J. P. Hay, Science 310 (2005) 1941-1943.

104. T. W. Hayton, J. M. Boncella, B. L. Scott, E. R. Batista and P. J. Hay, J. Am. Chem. Soc. 128 (2006) 10549-10559.

105. L. P. Spencer, R. L. Gdula, T. W. Hayton, B. L. Scott and J. M. Boncella, Chem. Commun. (2008) 4986-4988.

106. R. A. Eikey and M. M. Abu-Omar, Coord. Chem. Rev. 243 (2003) 83-124.

107. C. Vogel, F. W. Heinemann, J. Sutter, C. Anthon and K. Meyer, Angew. Chem. Int. Ed. 47 (2008) 2681-2684.

108. J. F. Berry, E. Bill, E. Bothe, S. D. George, B. Mienert, F. Neese and K. Wieghardt, Science 312 (2006) 1937-1941.

109. S. Fortier, G. Wu and T. W. Hayton, Dalton Trans. 39 (2010) 352-354.

110. R. K. Thomson, C. R. Graves, B. L. Scott and J. L. Kiplinger, Eur. J. Inorg. Chem. (2009) 1451-1455.

111. R. K. Thomson, B. L. Scott, D. E. Morris and J. L. Kiplinger, C. R. Chimie 13 (2010) 790-802.

112. R. K. Thomson, T. Cantat, B. L. Scott, D. E. Morris, E. R. Batista and J. L. Kiplinger, Nat. Chem. 2 (2010) 723-729.

113. J. C. Berthet and M. Ephritikhine, Coord. Chem. Rev. 178-180 (1998) 83-116.

114. D. M. King, F. Tuna, E. J. L. McInnes, J. McMaster, W. Lewis, A. J. Blake and S. T. Liddle, Science 337 (2012) 717-720.

115. M. Pepper and B. E. Bursten, Chem. Rev. 91 (1991) 719-741.

116. D. M. King, F. Tuna, E. J. L. McInnes, J. McMaster, W. Lewis, A. J. Blake and S. T. Liddle, Nat. Chem. 5 (2013) 482-488.

117. B. M. Gardner, J. C. Stewart, A. L. Davis, J. McMaster, W. Lewis, A. J. Blake, and S. T. Liddle, Proc. Nat. Acad. Sci. USA 109 (2012) 9265-9270.

118. B. M. Gardner, D. Patel, W. Lewis, A. J. Blake, and S. T. Liddle, Angew. Chem. Int. Ed. 50 (2011) 10440-10443.

119. B. M. Gardner, J. McMaster, W. Lewis, A. J. Blake and S. T. Liddle, J. Am. Chem. Soc. 131 (2009) 10388-10389. 
120. D. M. King, F. Tuna, J. McMaster, W. Lewis, A. J. Blake, E. J. L. McInnes, and S. T. Liddle, Angew. Chem. Int. Ed. 52 (2013) 4921-4924.

121. F. Haber, Ger. Pat. (1909) DE229126.

\section{ToC Entry}

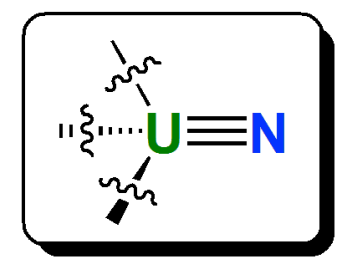

The chemistry of molecular uranium nitrides is reviewed.

\section{Highlights}

- Uranium nitride matrix isolation experiments reviewed.

- Aspects of uranium nitride materials chemistry and applications reviewed.

- Molecular bridging uranium nitrides reviewed.

- Photochemical approaches to terminal uranium nitrides reviewed.

- Molecular terminal uranium nitrides reviewed. 